\title{
Article \\ Autism-Related Transcription Factors Underlying the Sex-Specific Effects of Prenatal Bisphenol A Exposure on Transcriptome-Interactome Profiles in the Offspring Prefrontal Cortex
}

\author{
Songphon Kanlayaprasit ${ }^{1}$, Surangrat Thongkorn ${ }^{1}$, Pawinee Panjabud ${ }^{1}$, Depicha Jindatip ${ }^{2,3}{ }^{(0)}$, Valerie W. Hu ${ }^{4}(\mathbb{D}$, \\ Takako Kikkawa ${ }^{5}$, Noriko Osumi ${ }^{5}$ and Tewarit Sarachana ${ }^{2, *}$ (D)
}

Citation: Kanlayaprasit, S.;

Thongkorn, S.; Panjabud, P.; Jindatip, D.; Hu, V.W.; Kikkawa, T.; Osumi, N.;

Sarachana, T. Autism-Related

Transcription Factors Underlying the Sex-Specific Effects of Prenatal

Bisphenol A Exposure on

Transcriptome-Interactome Profiles in the Offspring Prefrontal Cortex. Int. J. Mol. Sci. 2021, 22, 13201. https:// doi.org/10.3390/ijms222413201

Academic Editor: Ashis Basu

Received: 22 November 2021

Accepted: 5 December 2021

Published: 8 December 2021

Publisher's Note: MDPI stays neutral with regard to jurisdictional claims in published maps and institutional affiliations.

Copyright: (c) 2021 by the authors. Licensee MDPI, Basel, Switzerland. This article is an open access article distributed under the terms and conditions of the Creative Commons Attribution (CC BY) license (https:// creativecommons.org/licenses/by/ $4.0 /)$.
1 The Ph.D. Program in Clinical Biochemistry and Molecular Medicine, Department of Clinical Chemistry, Faculty of Allied Health Sciences, Chulalongkorn University, Bangkok 10330, Thailand; songphon.ka@student.chula.ac.th (S.K.); 6176957037@student.chula.ac.th (S.T.); 6176952837@student.chula.ac.th (P.P.)

2 Systems Neuroscience of Autism and PSychiatric Disorders (SYNAPS) Research Unit, Department of Clinical Chemistry, Faculty of Allied Health Sciences, Chulalongkorn University, Bangkok 10330, Thailand; depicha.j@chula.ac.th

3 Department of Anatomy, Faculty of Medicine, Chulalongkorn University, Bangkok 10330, Thailand

4 Department of Biochemistry and Molecular Medicine, School of Medicine and Health Sciences, The George Washington University, Washington, DC 20052, USA; valhu@gwu.edu

5 Department of Developmental Neuroscience, United Centers for Advanced Research and Translational Medicine (ART), Tohoku University Graduate School of Medicine, Sendai 980-8577, Miyagi, Japan; kikkawa@med.tohoku.ac.jp (T.K.); osumi@med.tohoku.ac.jp (N.O.)

* Correspondence: tewarit.sa@chula.ac.th; Tel.: +66-2-218-1081 (ext. 313); Fax: +66-2-218-1082

Abstract: Bisphenol A (BPA) is an environmental risk factor for autism spectrum disorder (ASD). BPA exposure dysregulates ASD-related genes in the hippocampus and neurological functions of offspring. However, whether prenatal BPA exposure has an impact on genes in the prefrontal cortex, another brain region highly implicated in ASD, and through what mechanisms have not been investigated. Here, we demonstrated that prenatal BPA exposure disrupts the transcriptome-interactome profiles of the prefrontal cortex of neonatal rats. Interestingly, the list of BPA-responsive genes was significantly enriched with known ASD candidate genes, as well as genes that were dysregulated in the postmortem brain tissues of ASD cases from multiple independent studies. Moreover, several differentially expressed genes in the offspring's prefrontal cortex were the targets of ASD-related transcription factors, including AR, ESR1, and RORA. The hypergeometric distribution analysis revealed that BPA may regulate the expression of such genes through these transcription factors in a sex-dependent manner. The molecular docking analysis of BPA and ASD-related transcription factors revealed novel potential targets of BPA, including RORA, SOX5, TCF4, and YY1. Our findings indicated that prenatal BPA exposure disrupts ASD-related genes in the offspring's prefrontal cortex and may increase the risk of ASD through sex-dependent molecular mechanisms, which should be investigated further.

Keywords: endocrine-disrupting chemical; bisphenol A; prenatal exposure; autism spectrum disorder; sex differences; transcription factor; transcriptome; interactome; prefrontal cortex; molecular docking

\section{Introduction}

Autism spectrum disorder (ASD) is a neurodevelopmental disorder that can be diagnosed in early childhood and is characterized by two behavioral domains, i.e., social communication/interaction deficits and restricted interests or repetitive patterns of behavior according to the Diagnostic and Statistical Manual of Mental Disorders, 5th Edition 
(DSM-5) [1]. In the United States, the Centers for Disease Control and Prevention (CDC) estimated the prevalence of ASD in children by the age of eight to be 1 in 54, with at least four times higher in males than in females [2]. Although the exact causes and the sex bias of ASD are still unclear, there is accumulating evidence that genetic, epigenetic, and environmental factors are involved in ASD etiology and susceptibility [3-8]. Environmental factors that are associated with ASD include endocrine-disrupting chemicals (EDCs) $[5,9,10]$, heavy metals [11,12], smoke from cigarettes [13], and traffic-related air pollutants [14]. EDCs are chemical substances that potentially affect the hormonal system and disrupt homeostasis, reproduction, and developmental processes [5]. Examples of EDCs that have been linked to ASD are bisphenol A (BPA) [15,16], polychlorinated biphenyls (PCBs) [17], phthalates [18], and polybrominated diphenyl ethers (PBDEs) [19]. BPA $\left(\left(\mathrm{CH}_{3}\right)_{2} \mathrm{C}_{(}\left(\mathrm{C}_{6} \mathrm{H}_{4} \mathrm{OH}\right)_{2}\right)$ is an organic synthetic compound frequently found in polycarbonate plastic and epoxy resin products, the linings inside beverages and food cans, thermal paper, and dental sealants. In addition to such products, BPA is also found in polycarbonate micro/nanoplastics, which have become one of the major environmental problems worldwide $[20,21]$. When these products or micro/nanoplastics are exposed to high temperature or basic/acidic conditions, BPA can leach out and contaminate food or pollute the environment [20,22-24]. When ingested, the majority of BPA is converted to a conjugated form called BPA glucuronide in the liver and is then excreted through the urinary system $[25,26]$. The unconjugated BPA molecules remain circulating in the bloodstream and other tissues in the body [27-29]. Recent studies have shown that BPA can cross the placenta [30,31] and the blood-brain barriers [32,33] to reach the brains of offspring [34]. Recent findings have shown that humans are widely exposed to BPA [35,36]. The National Health and Nutrition Examination Survey (NHANES III) conducted by the CDC in 2003-2004 found detectable levels of BPA in as many as $93 \%$ of 2517 urine samples from participants who were at the age of six years and older [37]. Similar to a previous study conducted by the CDC, Hansen et al. found that BPA was detected in as many as $85.3 \%$ of maternal urine samples [38]. In addition to urine, other studies reported that BPA is also detectable in maternal and fetal sera [39], amniotic fluid [40], placenta [41], umbilical cords [42], colostrum [43], and breast milk [44]. In ASD populations, elevated levels of BPA have been observed in both the blood and urine of ASD cases [45-47]. Kardas et al. measured BPA concentrations in the serum of ASD and typically developing children using high-performance liquid chromatography (HPLC) and found that children with ASD have significantly higher serum BPA concentrations than typically developing children [46]. Similarly, Kondolot et al. found elevated levels of BPA in the plasma of children with pervasive developmental disorder not otherwise specified (PDD-NOS), which is a subtype of ASD [45]. Hansen et al. assessed the association between in utero exposure to BPA and ASD symptoms in Danish children and observed elevated odds ratios among 5-year-old children within the 3rd tertile of BPA exposure with an ASD score above the 75th percentile [38]. Their finding supports the hypothesis that prenatal BPA exposure may increase the risk of ASD symptoms. However, the effects of prenatal BPA exposure and the underlying molecular mechanisms in the context of ASD remain unclear.

The U.S. Food and Drug Administration (FDA) has determined the no-observedadverse-effect level (NOAEL) of BPA to be $5000 \mu \mathrm{g} / \mathrm{kg}$ maternal body weight/day [48,49]. However, there is accumulating evidence that exposure to BPA, even at the NOAEL dose or lower, can cause negative health effects [50-53]. Several studies have reported that BPA exposure has negative impacts on the central nervous system $[54,55]$, the reproductive system [56], the immune system [57], the digestive system [58], the thyroid [59], the liver [60], the heart [61], kidneys [62], and adipose tissues [63]. In the central nervous system, BPA alters neuronal viability [16], neuronal morphology [64], synaptogenesis [65], synaptic densities [65], and neocortical development [66,67]. It also causes behavioral alterations, including reduced social interaction [68], repetitive behaviors [69], impaired learning/memory [16], increased anxiety [70], hyperactivity [71], and inattention [72], all of which are associated with ASD [73-76]. However, the molecular mechanisms underlying 
the effects of BPA, particularly the neurological functions and behaviors associated with ASD, are still unclear.

Recent studies have shown that BPA exposure disrupts the expression of genes in several brain regions, including the prefrontal cortex [77], the hippocampus [15,78], the hypothalamus [78], the cerebellum [79], and the amygdala [80]. The prefrontal cortex is a brain region responsible for executive functions, including decision making, planning, prediction of outcomes, and social behavior, all of which are known to be impaired in people with ASD [81-83]. Moreover, several studies have shown that children with ASD exhibit an excess number of neurons [84] and decreased functional connectivity in the prefrontal cortex [85]. Using adult rats as a model, Castro et al. examined the effects of adult exposure to BPA on the expression of genes and proteins in the prefrontal cortex by real-time (RT)-PCR and Western blot analyses [77]. They found that BPA exposure increases the expression of cytochrome P450 aromatase and tryptophan hydroxylase 2 in male and female rats and decreases the expression of $5 \alpha$-reductase in females [77]. In addition to these genes, they also found that a total of 17 genes associated with prefrontal cortex functions are responsive to adult BPA exposure, indicating that BPA can alter the expression profiles of multiple genes in the prefrontal cortex region. It is noteworthy that cytochrome $\mathrm{P} 450$ aromatase - an enzyme responsible for estrogen biosynthesis from androgens-is associated with ASD and thought to be involved in the male bias of the disorder [86-88]. However, this study was focused on adult exposure and on genes known to be involved in drug- and chemical-induced neurotoxic responses. The effects of BPA on the transcriptome profiles of the prefrontal cortex and its association with ASD are unclear.

Our recent study demonstrated that prenatal BPA exposure alters the transcriptomeinteractome profiles of genes in the hippocampus of rat offspring [15]. Among those BPA-responsive genes are genes known to be associated with ASD and related neurological functions [15]. In addition, we also found that prenatal BPA exposure disrupts ASDrelated genes involved in neuronal viability, neuritogenesis, and learning/memory in a sex-dependent manner [16], suggesting that prenatal BPA exposure may play an important role in the risk and sex difference of ASD. However, the effects and mechanisms of prenatal BPA exposure on the transcriptome-interactome profiles of ASD-related genes in the prefrontal cortex have not been investigated.

In this study, we therefore sought to interrogate the effects and mechanisms of prenatal BPA exposure on the transcriptome-interactome profiles of genes in the prefrontal cortex of offspring, as well as determining the association of BPA-responsive genes and ASD. First, the RNA sequencing (RNA-seq) analysis of prefrontal cortex tissues isolated from neonatal rats prenatally exposed to BPA or vehicle control was performed. Then, the lists of differentially expressed genes (DEGs) from the RNA-seq analysis were analyzed by Ingenuity Pathway Analysis (IPA) software (QIAGEN Inc., Hilden, Germany, https: //www.qiagenbioinformatics.com/products/ingenuity-pathway-analysis/, accessed on 14 June 2019) [89] to predict biological functions and interactome networks associated with BPA-responsive genes and to determine whether BPA-responsive genes are associated with ASD. The link between the DEGs in the prefrontal cortex and ASD was also assessed by hypergeometric distribution analyses with the lists of ASD candidate genes from the ASD database SFARI. To further investigate whether these BPA-responsive genes were also found to be disrupted in the brains of ASD patients, we conducted a meta-analysis using transcriptome profiles of postmortem brain tissues from ASD patients and typically developing people from multiple independent studies that were published in the NCBI GEO Dataset database. The lists of BPA-responsive genes were then compared to DEGs in brain tissues of ASD cases using hypergeometric distribution analyses. BPA-responsive genes associated with ASD were selected for qRT-PCR analysis. To predict transcription factors involved in the effects of BPA on the transcriptome profiles in the prefrontal cortex, a list of transcription factors and the targets of each transcription factor were obtained and used for prediction. The molecular docking analysis of BPA and ASD-related transcription 
factors of which the targets were significantly enriched in the lists of BPA-responsive genes was further conducted to predict the binding affinity.

\section{Results}

2.1. Prenatal BPA Exposure Disrupts the Transcriptome Profiles of the Offspring's Prefrontal Cortex in a Sex-Dependent Manner

To investigate whether prenatal BPA exposure alters the transcriptome profiles of the offspring's prefrontal cortex, rat dams were treated with $5000 \mu \mathrm{g} / \mathrm{kg}$ maternal body weight or vehicle control daily using oral gavage from gestational day (GD) 1 until parturition. The dose of BPA used to treat rat dams in this study was equal to the NOAEL in humans as determined by the FDA. RNA-seq analysis was then performed using prefrontal cortex tissues isolated from neonatal male and female pups. To identify significantly differentially expressed transcripts in response to BPA, the RNA-seq data of male and female pups were then analyzed by combining both sexes into one group for each treatment (Table S1). The data of each sex of pups were also analyzed separately to gain insight into the sex difference in the effects of prenatal BPA exposure (Tables S2 and S3).

When the RNA-seq data of male and female pups in each treatment group were combined, a total of 16,182 transcripts corresponding to 14,144 genes were detectable in the prefrontal cortex of the pups. Among these, 7810 transcripts encoding 6284 genes were more significantly differentially expressed in the prefrontal cortex of rats prenatally exposed to BPA compared with in that of the controls $(p$-value $<0.05$ and false discovery rate $(\mathrm{FDR})<0.05)$. When each sex was analyzed separately, a total of 16,782 transcripts encoding 14,672 genes and 16,819 transcripts encoding 14,660 genes were detectable in the prefrontal cortex of male and female pups, respectively. We found that 3728 transcripts (corresponding to 2565 genes) were significantly differentially expressed in males, whereas 3830 transcripts (corresponding to 2706 genes) were differentially expressed in females in response to BPA ( $p$-value $<0.05$ and FDR $<0.05$ ). The lists of DEGs are shown in Tables S1-S3. This finding indicates that prenatal BPA exposure alters the transcriptome profiles of offspring's prefrontal cortex in a sex-dependent manner.

\subsection{BPA-Responsive Genes in the Prefrontal Cortex Are Associated with ASD and Related Neurological Functions and Pathways}

To determine whether genes differentially expressed in the offspring's prefrontal cortex in response to prenatal BPA exposure are associated with ASD or related biological functions and pathways, gene ontology analysis was performed using IPA software (Table 1, Tables S4 and S5).

Interestingly, we found that genes associated with "autism or intellectual disability" were significantly enriched in the lists of DEGs in the combined group (233 genes; $p$-value $\left.=4.11 \times 10^{-11}\right)$, male-only group $\left(128\right.$ genes; $p$-value $\left.=1.89 \times 10^{-13}\right)$, and femaleonly group $\left(105\right.$ genes; $p$-value $\left.=2.31 \times 10^{-5}\right)($ Table 1$)$. In addition, DEGs were also associated with other neurological disorders known to be comorbid disorders of ASD, including pervasive developmental disorder, schizophrenia spectrum disorder, movement disorders, and syndromic encephalopathy ( $p$-value $<0.05$ ). The biological function and canonical pathway analysis by IPA revealed that DEGs were related to neurological functions and pathways known to be disrupted in ASD, including axonal guidance signaling, PTEN signaling, synaptic long-term depression and potentiation, and Wnt/calcium signaling ( $p$-value < 0.05; Tables S4 and S5). "Proliferation of neuronal cells", "neuritogenesis", and "neurotransmission" were also highlighted. Notably, BPA-responsive genes in the prefrontal cortex of male pups, but not female pups, were also significantly associated with androgen signaling ( 63 genes; $p$-value $\left.=2.95 \times 10^{-4}\right)$ and estrogen receptor signaling (50 genes; $p$-value $=0.02$ ) (Table S5), both of which have been implicated in the male bias of ASD. 
Table 1. Neurological disorders associated with differentially expressed genes (DEGs) in the offspring's prefrontal cortex in response to prenatal bisphenol A (BPA) exposure. The lists show the DEGs in the prefrontal cortex of rat pups prenatally exposed to BPA when both male and female pups were combined into one group for each treatment and each sex of pups was analyzed. $p$-value $<0.05$ was considered as significant. NS, not significant. NA, not available.

\begin{tabular}{cccc}
\hline Diseases or Disorders & \multicolumn{3}{c}{$p$-Value (Number of Genes) } \\
\cline { 2 - 4 } & Both Sexes & Male & Female \\
\hline Autism or intellectual disability & $4.11 \times 10^{-11}(233)$ & $1.89 \times 10^{-13}(128)$ & $2.31 \times 10^{-5}(105)$ \\
\hline Schizophrenia spectrum disorder & $\mathrm{NS}$ & $3.64 \times 10^{-8}(128)$ & $1.75 \times 10^{-9}(139)$ \\
\hline Mood disorders & $4.82 \times 10^{-10}(227)$ & $3.40 \times 10^{-8}(111)$ & $1.27 \times 10^{-6}(110)$ \\
\hline Pervasive developmental disorder & $2.05 \times 10^{-7}(107)$ & $4.92 \times 10^{-5}(50)$ & NA \\
\hline Disorder of basal ganglia & $1.15 \times 10^{-23}(516)$ & $1.60 \times 10^{-12}(186)$ & $1.42 \times 10^{-11}(191)$ \\
\hline Movement disorders & $4.36 \times 10^{-37}(760)$ & $5.32 \times 10^{-16}(234)$ & $1.96 \times 10^{-14}(239)$ \\
\hline Amyotrophic lateral sclerosis & $\mathrm{NA}$ & $1.84 \times 10^{-6}(59)$ & $3.57 \times 10^{-9}(69)$ \\
\hline Alzheimer disease & $6.74 \times 10^{-19}(347)$ & $3.35 \times 10^{-11}(163)$ & $1.28 \times 10^{-11}(172)$ \\
\hline Huntington's disease & $6.54 \times 10^{-19}(388)$ & $6.67 \times 10^{-9}(126)$ & $2.30 \times 10^{-10}(137)$ \\
\hline Syndromic encephalopathy & $3.77 \times 10^{-21}(358)$ & $1.49 \times 10^{-7}(75)$ & $5.82 \times 10^{-6}(73)$ \\
\hline
\end{tabular}

To visualize the interactions among DEGs in the prefrontal cortex as well as the association between DEGs and diseases/functions associated with ASD, an interactome network analysis was performed using IPA software (Figure S1). The interactome network of DEGs from the both-sex group showed the interaction of DEGs and ASD-related pathological conditions, including "intellectual disability" and "sensory and motor neuropathy". Notably, Lnpk-a gene associated with autistic features-was shown to be the hub gene of the interactome network (Figure S1A). The interactome networks of DEGs in male and female pups prenatally exposed to BPA also showed associations with neurological disorders and functions linked to the development of the prefrontal cortex and ASD, including "autism spectrum disorder", "neurodevelopmental disorder", "developmental delay", "learning", "formation of the forebrain", "development of cortical plate", and "neuritogenesis" (Figure S1B,C). These findings suggest that prenatal exposure to BPA alters the expression profiles of genes associated with ASD or related neurological functions in the prefrontal cortex in a sex-specific pattern.

\subsection{Known ASD Candidate Genes Are Significantly Enriched in the Lists of BPA-Responsive Genes in the Prefrontal Cortex}

To further examine whether BPA-responsive genes are significantly associated with genes previously reported in the literature to be ASD candidate genes, the lists of DEGs in the offspring's prefrontal cortex were compared to the lists of known ASD candidate genes obtained from the ASD database SFARI. Hypergeometric distribution analysis was then performed to determine the statistical significance of the association between DEGs and known ASD candidate genes with different confidence levels determined by the SFARI database (Table 2). 
Table 2. Associations between the BPA-responsive genes and the known ASD candidate genes from the SFARI database. Hypergeometric distribution analysis was performed to determine the associations between the lists of BPA-responsive genes in the offspring's prefrontal cortex and the known ASD candidate genes from the SFARI database. The scores determined by the SFARI database indicate confidence levels for each group of ASD candidate genes. Statistically significant associations were determined by hypergeometric distribution analysis ( $p$-value $<0.05$ ).

\begin{tabular}{|c|c|c|c|c|c|c|}
\hline \multirow[b]{2}{*}{$\begin{array}{l}\text { Gene List Category } \\
\text { (No. of Genes) }\end{array}$} & \multicolumn{2}{|c|}{ Both Sexes } & \multicolumn{2}{|c|}{ Male } & \multicolumn{2}{|c|}{ Female } \\
\hline & $\begin{array}{c}\text { No. of Target } \\
\text { Genes Detected } \\
\text { in the Rat Frontal } \\
\text { Cortex }\end{array}$ & $\begin{array}{l}\text { No. of Overlapping } \\
\text { Genes ( } p \text {-Value) }\end{array}$ & $\begin{array}{c}\text { No. of Target } \\
\text { Genes Detected in } \\
\text { the Rat Frontal } \\
\text { Cortex }\end{array}$ & $\begin{array}{l}\text { No. of Overlapping } \\
\text { Genes ( } p \text {-Value) }\end{array}$ & $\begin{array}{c}\text { No. of Target } \\
\text { Genes Detected } \\
\text { in the Rat Frontal } \\
\text { Cortex }\end{array}$ & $\begin{array}{l}\text { No. of Overlapping } \\
\text { Genes ( } p \text {-Value) }\end{array}$ \\
\hline All genes (986) & 835 & $408\left(4.44 \times 10^{-3}\right)$ & 847 & $243\left(6.64 \times 10^{-17}\right)$ & 843 & $228\left(1.70 \times 10^{-10}\right)$ \\
\hline Syndromic (143) & 130 & $66(0.085)$ & 133 & $49\left(7.32 \times 10^{-8}\right)$ & 129 & $38\left(1.54 \times 10^{-3}\right)$ \\
\hline $\begin{array}{c}\text { Score 1 } \\
\text { High confidence (25) }\end{array}$ & 23 & $10(0.615)$ & 23 & $10\left(3.27 \times 10^{-3}\right)$ & 23 & $11\left(1.25 \times 10^{-3}\right)$ \\
\hline $\begin{array}{c}\text { Score } 2 \\
\text { Strong candidate (59) }\end{array}$ & 54 & $24(0.552)$ & 55 & $18\left(4.45 \times 10^{-3}\right)$ & 55 & $17\left(1.77 \times 10^{-2}\right)$ \\
\hline $\begin{array}{c}\text { Score } 3 \\
\text { Suggestive evidence } \\
(176)\end{array}$ & 159 & $70(0.572)$ & 163 & $53\left(2.11 \times 10^{-6}\right)$ & 159 & $52\left(1.10 \times 10^{-5}\right)$ \\
\hline $\begin{array}{c}\text { Score } 4 \\
\text { Minimal evidence (406) }\end{array}$ & 321 & $162\left(1.62 \times 10^{-2}\right)$ & 322 & $90\left(1.70 \times 10^{-6}\right)$ & 324 & $84\left(4.84 \times 10^{-4}\right)$ \\
\hline $\begin{array}{c}\text { Score } 5 \\
\text { Hypothesized (157) }\end{array}$ & 133 & $68(0.071)$ & 135 & $28(0.186)$ & 136 & $30(0.164)$ \\
\hline
\end{tabular}

Consistent with the gene ontology analysis using IPA, known ASD candidate genes with high confidence levels identified by the SFARI database as "syndromic", "high confidence", and "strong candidate" genes were significantly enriched in the lists of DEGs in the prefrontal cortex of male and female pups prenatally exposed to BPA. When both sexes of pups were combined into one group for each treatment, as many as 408 known ASD candidate genes were significantly enriched in the list of DEGs ( $p$-value $\left.=4.44 \times 10^{-3}\right)$. The highly significant associations between the lists of DEGs and the known ASD candidate genes were also observed, when male and female rat pups were analyzed separately (243 genes, $p$-value $=6.64 \times 10^{-17}$ in males; 228 genes, $p$-value $=1.70 \times 10^{-10}$ in females). The lists of DEGs that are the known ASD candidate genes as well as the confidence categories identified by the SFARI database are shown in Tables S6-S8.

To further confirm that prenatal BPA exposure dysregulates the expression of ASDrelated genes in the offspring's prefrontal cortex, five ASD candidate genes, which were Ntng1 (netrin G1), Auts2 (autism susceptibility gene 2 or activator of transcription and developmental regulator AUTS2), Ankrd11 (ankyrin repeat domain 11), Dock4 (dedicator of cytokinesis 4), and Syne1 (spectrin repeat containing nuclear envelope protein 1), were selected for qRT-PCR analysis (Figure 1). These ASD candidate genes were selected, because they are known to be abundantly expressed in the cortex during embryogenesis and involved in neuronal development during the prenatal period [90-95]. We found that Ntng1 was significantly reduced whereas Auts2 and Ankrd11 were upregulated in response to prenatal BPA exposure (Figure 1). Interestingly, the significant downregulation of Ntng1 and the upregulation of Ankrd11 were observed in female pups only. 

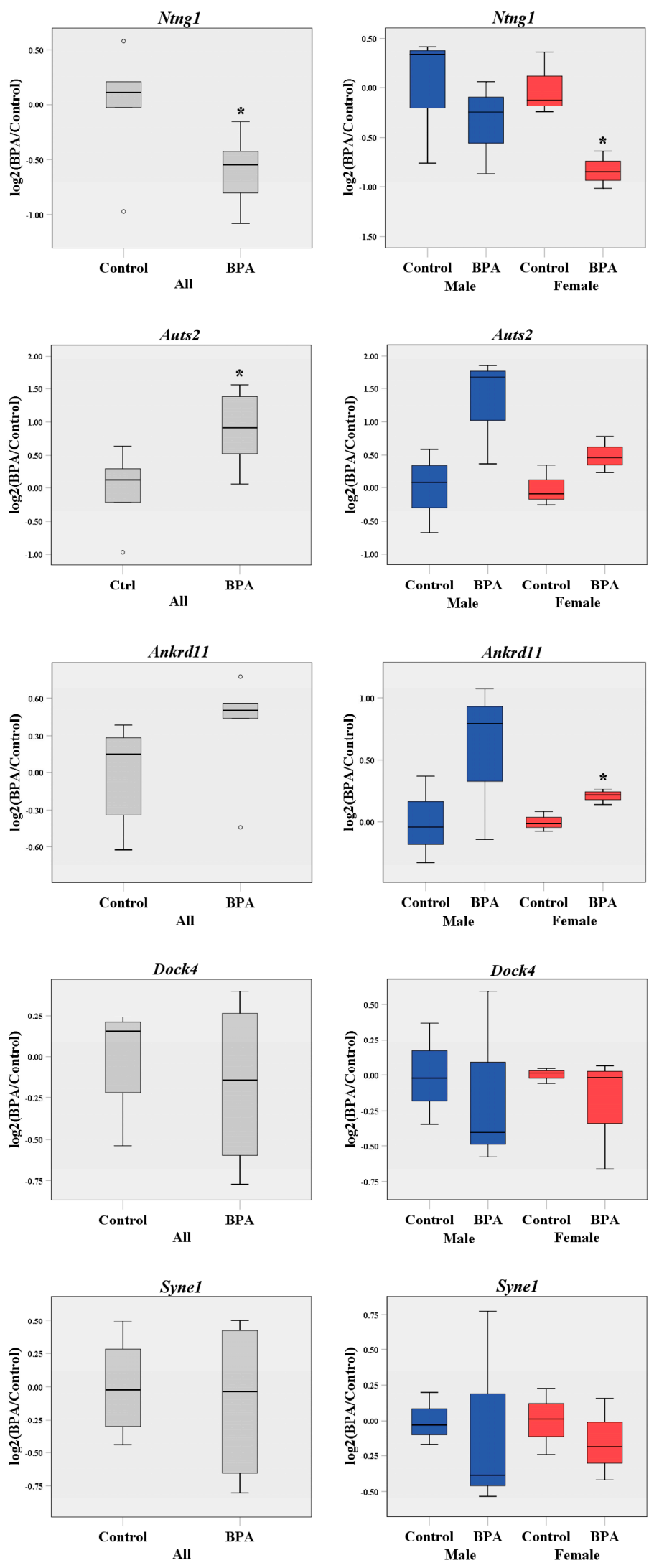

Figure 1. Box plot of autism spectrum disorder (ASD)-related gene expression in the prefrontal cortex tissues. The expression levels of Ntng1, Auts2, Ankrd11, Dock4, and Syne1 were determined in both sexes ( $n=6$ pups/group; male pups $=3$ and female pups $=3$ ) and separately in males and females ( $n=3 \mathrm{pups} / \mathrm{sex} /$ treatment group). ${ }^{*} p$-value $<0.05$. 


\subsection{BPA-Responsive Genes Are Significantly Associated with DEGs in Postmortem Brain Tissues from ASD Cases}

Next, we sought to further investigate whether DEGs in response to prenatal BPA exposure in the offspring's prefrontal cortex were also found to be dysregulated in the brains of ASD patients. The transcriptome profiling data of postmortem brain tissues from people with ASD and typically developing people were obtained from the NCBI GEO database and reanalyzed using $\mathrm{MeV}$ software to identify genes that were significantly differentially expressed in ASD brain tissues. The details of transcriptome datasets and human brain samples are provided in Table S9. The lists of BPA-responsive genes in the rat offspring prefrontal cortex were then compared with DEGs in ASD brain tissues, and hypergeometric distribution analyses were performed to assess the statistical significance of the association. Interestingly, we found that BPA-responsive genes were significantly associated with DEGs in ASD brain samples from multiple independent transcriptomic profiling datasets, particularly with DEGs in ASD frontal and temporal cortex tissues (Table 3). The lists of BPA-responsive genes in the rat offspring prefrontal cortex that were also found to be dysregulated in ASD brain tissues from each transcriptomic dataset are shown in Tables S10-S12.

Table 3. Associations between BPA-responsive genes and DEGs from postmortem brain tissues of people with ASD. Hypergeometric distribution analysis was performed to determine the associations between the lists of BPA-responsive genes in the offspring's prefrontal cortex and genes differentially expressed in the brain of ASD cases. Statistically significant associations were determined by hypergeometric distribution analysis ( $p$-value $<0.05$ ).

\begin{tabular}{|c|c|c|c|c|c|c|c|c|c|c|}
\hline \multirow[b]{2}{*}{$\begin{array}{l}\text { Studies } \\
\text { (Year) }\end{array}$} & \multirow[b]{2}{*}{$\begin{array}{l}\text { Brain } \\
\text { Region }\end{array}$} & \multicolumn{3}{|c|}{ Both Sexes (6284 Genes) } & \multicolumn{3}{|c|}{ Male (2565 Genes) } & \multicolumn{3}{|c|}{ Female (2706 Genes) } \\
\hline & & $\begin{array}{l}\text { No. of } \\
\text { DEGs } \\
\text { Detected } \\
\text { in the Rat } \\
\text { Frontal } \\
\text { Cortex }\end{array}$ & $\begin{array}{l}\text { No. of } \\
\text { Overlap- } \\
\text { ping } \\
\text { Genes }\end{array}$ & $p$-Value & $\begin{array}{l}\text { No. of } \\
\text { DEGs } \\
\text { Detected } \\
\text { in the Rat } \\
\text { Frontal } \\
\text { Cortex }\end{array}$ & $\begin{array}{l}\text { No. of } \\
\text { Overlap- } \\
\text { ping } \\
\text { Genes }\end{array}$ & $p$-Value & $\begin{array}{c}\text { No. of } \\
\text { DEGs } \\
\text { Detected } \\
\text { in the Rat } \\
\text { Frontal } \\
\text { Cortex }\end{array}$ & $\begin{array}{l}\text { No. of } \\
\text { Overlap- } \\
\text { ping } \\
\text { Genes }\end{array}$ & $p$-Value \\
\hline $\begin{array}{l}\text { Parikshak } \\
\text { et al. (2015) }\end{array}$ & $\begin{array}{l}\text { Frontal and } \\
\text { temporal } \\
\text { cortex }\end{array}$ & 954 & 462 & $\begin{array}{c}5.61 \times \\
10^{-3}\end{array}$ & 956 & 221 & $\begin{array}{c}2.71 \times \\
10^{-6}\end{array}$ & 958 & 219 & $\begin{array}{c}2.28 \times \\
10^{-4}\end{array}$ \\
\hline $\begin{array}{l}\text { Voineagu } \\
\text { et al. (2011) }\end{array}$ & $\begin{array}{c}\text { Frontal } \\
\text { cortex } \\
\text { (BA9, } \\
\text { BA44/45) }\end{array}$ & 384 & 177 & 0.269 & 383 & 89 & $\begin{array}{c}2.22 \times \\
10^{-3}\end{array}$ & 385 & 86 & 0.029 \\
\hline $\begin{array}{l}\text { Chow et al. } \\
\text { (2012) }\end{array}$ & $\begin{array}{l}\text { Prefrontal } \\
\text { cortex }\end{array}$ & 71 & 36 & 0.172 & 76 & 24 & $\begin{array}{c}1.94 \times \\
10^{-3}\end{array}$ & 73 & 16 & 0.264 \\
\hline $\begin{array}{l}\text { Garbett et. } \\
\text { al. (2008) }\end{array}$ & $\begin{array}{l}\text { Temporal } \\
\text { cortex }\end{array}$ & 101 & 58 & $\begin{array}{c}5.72 \times \\
10^{-3}\end{array}$ & 102 & 21 & 0.238 & 101 & 29 & $\begin{array}{c}7.72 \times \\
10^{-3}\end{array}$ \\
\hline $\begin{array}{l}\text { Voineagu } \\
\text { et al. (2011) }\end{array}$ & $\begin{array}{c}\text { Temporal } \\
\text { cortex } \\
(\mathrm{BA} 41 / 42, \\
22)\end{array}$ & 545 & 248 & 0.318 & 546 & 117 & $\begin{array}{c}8.98 \times \\
10^{-3}\end{array}$ & 539 & 120 & 0.013 \\
\hline $\begin{array}{l}\text { Ginsberg } \\
\text { et al. (2012) }\end{array}$ & $\begin{array}{l}\text { Occipital } \\
\text { lobe } \\
\text { (BA19) }\end{array}$ & 269 & 116 & 0.690 & 270 & 60 & 0.026 & 277 & 56 & 0.245 \\
\hline $\begin{array}{l}\text { Ginsberg } \\
\text { et al. (2012) }\end{array}$ & Cerebellum & 749 & 307 & 0.977 & 744 & 150 & 0.029 & 746 & 151 & 0.108 \\
\hline $\begin{array}{l}\text { Voineagu } \\
\text { et al. (2011) }\end{array}$ & $\begin{array}{l}\text { Cerebellum; } \\
\text { vermis }\end{array}$ & 57 & 24 & 0.685 & 58 & 12 & 0.309 & 58 & 11 & 0.514 \\
\hline
\end{tabular}

\subsection{Identification of Upstream Regulators of DEGs in Response to Prenatal BPA Exposure}

Recent studies have shown that BPA can interact with several transcription factors, including AR [96], ESR1 [97], ERRG [97], PPARG [97], and THRA [98]. However, it is still unclear what transcription factors are responsible for the neurotoxicity mediated by prenatal BPA exposure. To identify potential transcription factors through which BPA exerts its negative effects on transcriptome profiles of the offspring's prefrontal cortex, the list of all known transcription factors was obtained from the Human Transcription Factors database [99]. Out of 1639 transcription factors available in the Human Transcription Factors database, a total of 96 transcription factors are associated with ASD and found in 
the SFARI database [100]. Then, the targets of each transcription factor were obtained from the TRANSFAC Curated, TRANSFAC Predicted, CHEA, ENCODE, JASPAR Predicted, and MotifMap Predicted databases through the Harmonizome database (Table S13). Among 96 ASD-related transcription factors, the targets of 34 transcription factors are available in the Harmonizome database, with 14 transcription factors of which the target genes are manually curated by the TRANSFAC Curated Transcription Factor Targets database [101,102]. We then performed the hypergeometric distribution analysis between the lists of BPAresponsive genes and the targets of each transcription factor available in the Harmonizome database to examine whether the targets of ASD-related transcription factors were significantly enriched in the lists of BPA-responsive genes. The hypergeometric distribution analysis revealed the significant associations between BPA-responsive genes and the targets of 25 transcription factors (Table S13). Out of 25 significant transcription factors, the targets of 10 transcription factors, including AR, ESR1, RORA, SOX5, TCF4, and YY1, are manually curated and available in the TRANSFAC Curated database (Table 4).

Table 4. ASD-related transcription factors of which the target genes are over-represented among BPA-responsive genes in the offspring prefrontal cortex. Hypergeometric distribution analyses were performed to determine the associations between the BPA-responsive genes in the offspring prefrontal cortex and the lists of target genes of each autism-related transcription factor that are manually curated and available in the TRANSFAC Curated database. A $p$-value of $<0.05$ is considered as significant.

\begin{tabular}{|c|c|c|c|c|c|c|}
\hline \multirow[b]{2}{*}{$\begin{array}{l}\text { Transcription } \\
\text { Factors }\end{array}$} & \multicolumn{2}{|c|}{ Both Sexes (6284 Genes) } & \multicolumn{2}{|c|}{ Male (2565 Genes) } & \multicolumn{2}{|c|}{ Female (2706 Genes) } \\
\hline & $\begin{array}{c}\text { No. of Target } \\
\text { Genes Detected in } \\
\text { the Rat Frontal } \\
\text { Cortex }\end{array}$ & $\begin{array}{c}\text { No. of Overlapping } \\
\text { Genes } \\
(p \text {-Value })\end{array}$ & $\begin{array}{c}\text { No. of Target } \\
\text { Genes Detected in } \\
\text { the Rat Frontal } \\
\text { Cortex }\end{array}$ & $\begin{array}{c}\text { No. of Overlapping } \\
\text { Genes } \\
(p \text {-Value })\end{array}$ & $\begin{array}{l}\text { No. of Target } \\
\text { Genes Detected in } \\
\text { the Rat Frontal } \\
\text { Cortex }\end{array}$ & $\begin{array}{c}\text { No. of Overlapping } \\
\text { Genes } \\
(p \text {-Value })\end{array}$ \\
\hline $\mathrm{AR}$ & 609 & $274(0.403)$ & 614 & $140\left(3.56 \times 10^{-4}\right)$ & 618 & $145\left(8.48 \times 10^{-4}\right)$ \\
\hline CUX1 & 360 & $161(0.475)$ & 371 & $77(0.056)$ & 366 & $82\left(3.07 \times 10^{-2}\right)$ \\
\hline EGR2 & 173 & $80(0.342)$ & 170 & $37(0.087)$ & 171 & $42\left(2.74 \times 10^{-2}\right)$ \\
\hline ESR1 & 372 & $178(0.098)$ & 380 & $81\left(2.93 \times 10^{-2}\right)$ & 378 & $82(0.060)$ \\
\hline MTF1 & 211 & $103(0.111)$ & 220 & $54\left(4.78 \times 10^{-3}\right)$ & 213 & $50\left(3.79 \times 10^{-2}\right)$ \\
\hline PAX5 & 137 & $67(0.165)$ & 137 & $26(0.355)$ & 138 & $32(0.094)$ \\
\hline PAX6 & 85 & $42(0.206)$ & 85 & $15(0.529)$ & 84 & $16(0.489)$ \\
\hline POU3F2 & 435 & $189(0.679)$ & 437 & $96\left(8.54 \times 10^{-3}\right)$ & 441 & $90(0.156)$ \\
\hline RORA & 264 & $109(0.864)$ & 266 & $63\left(5.84 \times 10^{-3}\right)$ & 266 & $69\left(1.45 \times 10^{-3}\right)$ \\
\hline SMAD4 & 196 & $86(0.589)$ & 195 & $39(0.200)$ & 194 & $31(0.839)$ \\
\hline SOX5 & 219 & $104(0.198)$ & 214 & $56\left(8.80 \times 10^{-4}\right)$ & 221 & $55\left(1.01 \times 10^{-2}\right)$ \\
\hline STAT1 & 304 & $130(0.741)$ & 305 & $64(0.063)$ & 306 & $64(0.148)$ \\
\hline TCF4 & 375 & $187\left(1.83 \times 10^{-2}\right)$ & 379 & $96\left(6.38 \times 10^{-5}\right)$ & 377 & $94\left(9.40 \times 10^{-4}\right)$ \\
\hline YY1 & 633 & $259(0.969)$ & 645 & $145\left(5.38 \times 10^{-4}\right)$ & 634 & $114(0.641)$ \\
\hline
\end{tabular}

To further examine whether the targets of RORA in neuronal cells were enriched in BPA-responsive genes, we obtained the list of RORA transcriptional targets from our previous study. Using chromatin immunoprecipitation (ChIP) followed by whole-genome promoter array (chip) analysis, we found that RORA1-a major isoform of RORA protein in the human brain - was recruited to as many as 2764 genomic locations corresponding to promoter regions of 2544 genes across the human genome [103]. The hypergeometric distribution analysis unveiled the strong associations between the BPA-responsive genes and the RORA1 transcription targets (Table S14), suggesting that RORA is involved in the effects of prenatal BPA exposure on gene expression in the prefrontal cortex. Notably, the BPA-responsive genes in male and female pups exhibited sex-specific associations with the targets of ASD-related transcription factors. This finding suggests that the BPA-mediated dysregulation of transcriptome profiles in the prefrontal cortex of male and female offspring may involve different sets of transcription factors. 


\subsection{Molecular Docking Analysis of BPA and ASD-Related Transcription Factors of Which the} Targets Are Over-Represented among BPA-Responsive Genes

To predict whether BPA can directly interact with ASD-related transcription factors, we selected 10 transcription factors of which the targets are associated with BPAresponsive genes and manually curated them by the TRANSFAC Curated database. We performed molecular docking analysis with BPA molecules using Discovery Studio 2019 and AutoDock 4.2 software (Figure S2). The binding free energies of the complexes between BPA and each transcription factor were calculated. When available, the known ligands of each transcription factor were also used in molecular docking analysis for comparison. The molecular docking analysis revealed that BPA exhibited good binding affinity with AR, ESR1, RORA, SOX5, TCF4, and YY1 (Table 5). We also investigated the expression of genes encoding these transcription factor proteins (Figure S3A,B). The qRT-PCR analysis of Ar and $Y_{y} 1$ showed that the RNA levels of these transcription factors were not significantly changed in response to BPA, suggesting that BPA may interact with these transcription factor proteins and alter the activities of these transcription factors at the protein level without changing the RNA expression.

Table 5. Molecular docking of ASD-related transcription factors of which the targets were over-represented in BPAresponsive genes and BPA. The molecular docking between ASD-related transcription factors of which the targets were enriched among BPA-responsive genes in the offspring frontal cortex was performed using Discovery Studio 2019 and Autodock 4.2 software. The mean value and standard deviation of binding free energy for each pair of transcription factor and BPA or known ligand were calculated from triplicates. NA, not available.

\begin{tabular}{|c|c|c|c|c|c|}
\hline \multirow{2}{*}{ Protein ID } & \multirow{2}{*}{ TFs } & \multirow{2}{*}{ Name } & \multirow{2}{*}{ Known Ligand } & \multicolumn{2}{|c|}{ Mean Binding Free Energy \pm SD (kcal/mol) } \\
\hline & & & & Known Ligand & BPA Ligand \\
\hline \multirow{2}{*}{ PDB:2AM9 } & \multirow{2}{*}{$\mathrm{AR}$} & \multirow{2}{*}{ Androgen receptor } & Testosterone & $-11.17 \pm 0.00$ & \multirow{2}{*}{$-8.98 \pm 0.01$} \\
\hline & & & $5 \beta$-dihydrotestosterone & $-11.07 \pm 0.00$ & \\
\hline PDB: 1A52 & ESR1 & Estrogen receptor alpha & $17 \beta$-estradiol & $-9.96 \pm 0.00$ & $-7.49 \pm 0.00$ \\
\hline \multirow{2}{*}{ PDB:1S0X } & \multirow{2}{*}{ RORA } & \multirow{2}{*}{$\begin{array}{l}\text { Retinoic acid-related } \\
\text { orphan receptor-alpha }\end{array}$} & Cholesterol sulfate [104] & $-12.64 \pm 0.18$ & \multirow{2}{*}{$-7.47 \pm 0.04$} \\
\hline & & & $\begin{array}{c}7 \beta \text {-hydroxycholesterol } \\
{[104]}\end{array}$ & $-11.05 \pm 0.16$ & \\
\hline PDB:1I11 & SOX5 & $\begin{array}{c}\text { SRY-box } 5 \\
\text { (DNA-binding domain) }\end{array}$ & NA & NA & $-5.85 \pm 0.01$ \\
\hline PDB:2KWF & TCF4 & Transcription factor 4 & NA & NA & $-5.75 \pm 0.04$ \\
\hline PDB:1UBD & YY1 & $\begin{array}{c}\text { Yin Yang } 1 \\
\text { transcriptional } \\
\text { repressor protein } \\
\text { (Zinc-finger domain) }\end{array}$ & NA & NA & $-5.68 \pm 0.02$ \\
\hline Alphafold ID: Q14872 & MTF1 & $\begin{array}{c}\text { Metal regulatory } \\
\text { transcription factor } 1\end{array}$ & NA & NA & $-4.33 \pm 0.05$ \\
\hline Alphafold ID: P20265 & POU3F2 & $\begin{array}{l}\text { POU domain, class } 3, \\
\text { and transcription factor } \\
2\end{array}$ & NA & NA & $-4.33 \pm 0.38$ \\
\hline Alphafold ID: P39880 & CUX1 & $\begin{array}{l}\text { Homeobox protein } \\
\text { cut-like } 1\end{array}$ & NA & NA & $-4.15 \pm 0.37$ \\
\hline Alphafold ID: P11161 & EGR2 & $\begin{array}{c}\text { E3 SUMO-protein ligase } \\
\text { EGR2 }\end{array}$ & NA & NA & $-3.66 \pm 0.14$ \\
\hline
\end{tabular}

Moreover, we found that BPA can bind to the ligand-binding domains of AR, ESR1, and RORA at sites close to the known ligands of these transcription factors (Figure 2). These results suggest that BPA may alter the transcription of their target genes in the prefrontal cortex of offspring by interacting with these transcription factors. 
A

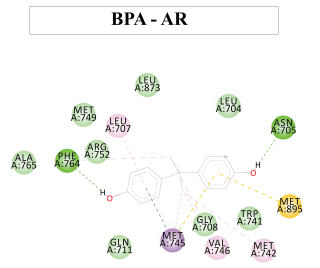

를

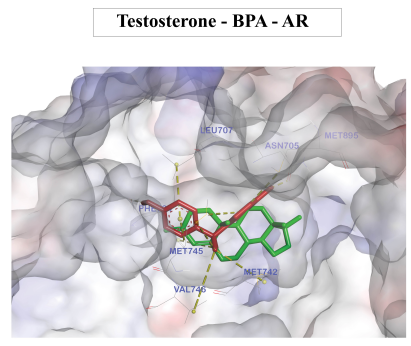

5B-dihydrotestosterone - BPA - AR

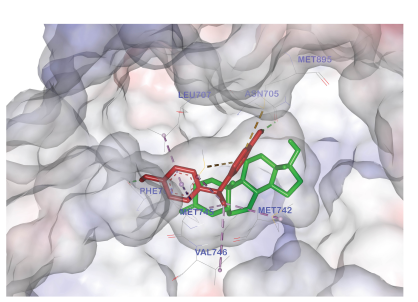

177-estradiol - BPA - ESR1

B

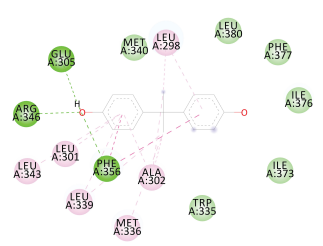

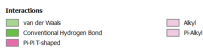

C

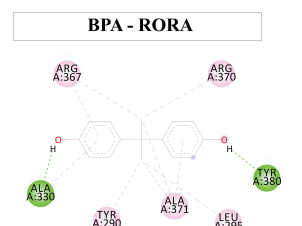

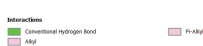
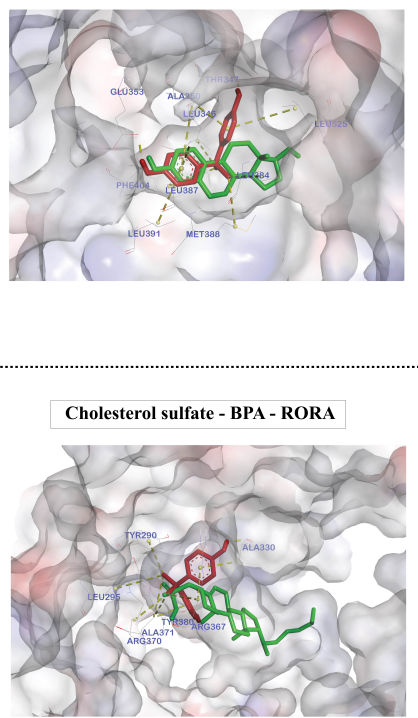

7ß-hydroxycholesterol - BPA - RORA

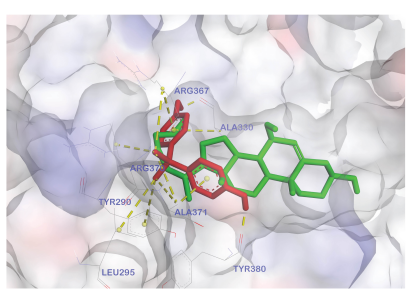

Figure 2. Molecular docking of BPA and AR/ESR1/RORA, of which the targets were overrepresented among BPA-responsive genes in the offspring prefrontal cortex. The molecular docking between BPA (red) and androgen receptor (AR) (A), estrogen receptor alpha (ESR1) (B), and retinoic acid-related orphan receptor-alpha (RORA) (C) was performed using Discovery Studio 2019 and Autodock 4.2 software. The known ligands (green) of these transcription factors were also used for comparison.

\section{Discussion}

Although ASD has a high degree of heritability and genetic factors are known to play an important role in the etiology and susceptibility of the disorder [105-107], recent evi- 
dence has shown that up to $40-50 \%$ of variance in the genetic liability of ASD is determined by environmental factors [108-112]. Recent human studies have reported that in utero BPA exposure is associated with altered behaviors and neurological functions frequently found in ASD [113-122], prompting the theory that exposure to BPA may cause or increase the risk of the disorder. Several animal studies have investigated the effects of adult or prenatal BPA exposure on the brain and found that BPA dysregulates gene expression in multiple regions, including the prefrontal cortex [77], the hippocampus [15,78], the hypothalamus [78], the amygdala [80], and the cerebellum [79]. Although these brain regions are known to be impacted in people with ASD [123,124], it is still unclear how prenatal BPA exposure can cause pathological conditions in the brain and lead to behavioral impairments that are the hallmarks of ASD. Moreover, the effects of in utero BPA exposure on the transcriptome profiles of the offspring's prefrontal cortex-a brain region responsible for executive functions and social behaviors known to be negatively impacted in ASD-have not been investigated. This is the first study to demonstrate that prenatal BPA exposure, even at the (NOAEL), alters the transcriptome-interactome profiles of genes in the offspring's prefrontal cortex in a sex-dependent manner, possibly through ASD-related transcription factors (Figure 3).

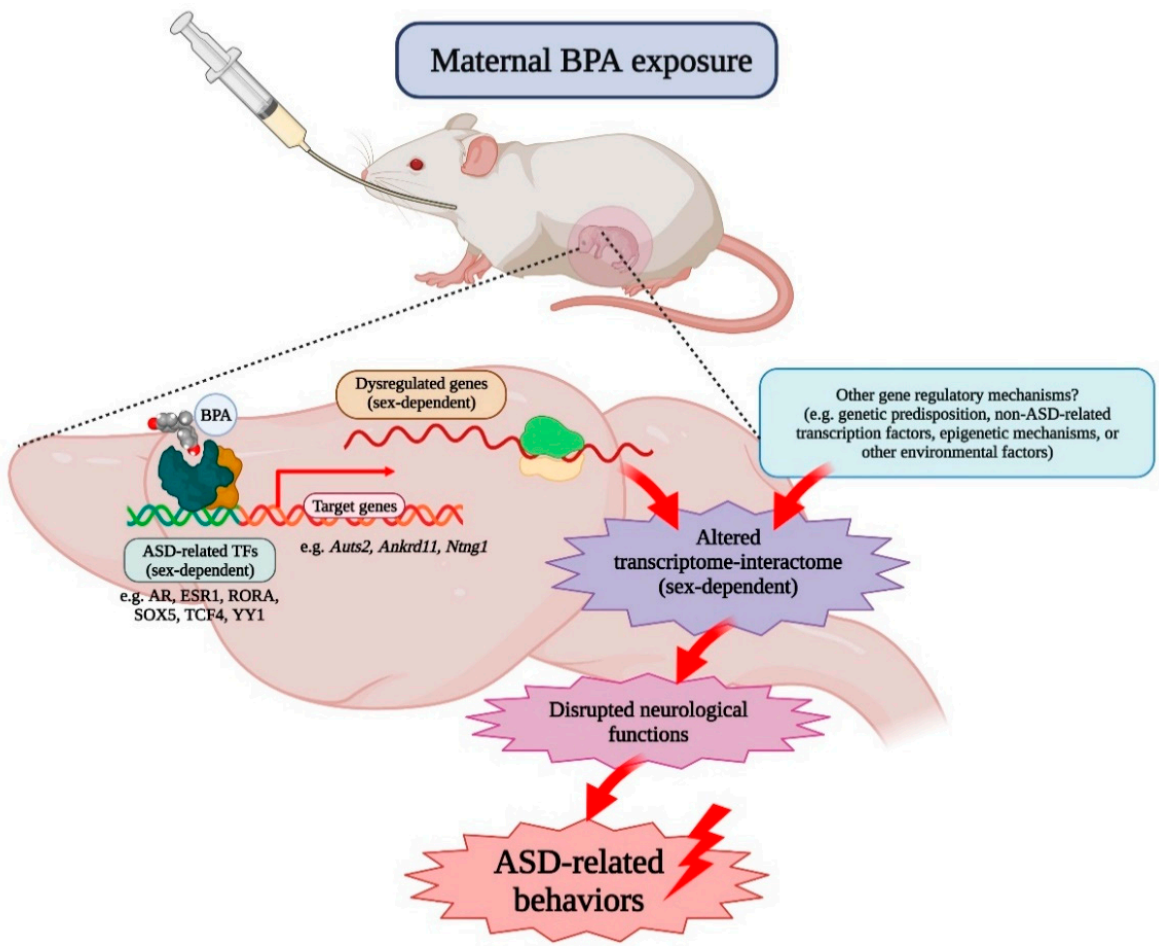

Figure 3. Schematic diagram illustrating a possible mechanism of prenatal BPA exposure on the offspring prefrontal cortex. We propose that maternal BPA exposure alters the transcriptomeinteractome profiles in the prefrontal cortex of offspring in a sex-dependent manner through ASDrelated transcription factors (e.g., AR, ESR1, RORA, SOX5, TCF4, and YY1), as well as other gene regulatory mechanisms (e.g., genetic predisposition, non-ASD-related transcription factors, epigenetic mechanisms, or other environmental factors). Disrupted transcriptome-interactome profiles lead to neuropathological conditions in the ASD brain and changes in behaviors that are controlled by the prefrontal cortex and known to be negatively impacted in ASD, such as social interaction and executive functions. (This figure was created with BioRender.com).

This finding is consistent with our previous studies, which observed the sex-specific effects of maternal BPA exposure on the transcriptome-interactome profiles of the offspring hippocampus $[15,16,125]$. Moreover, Thongkorn et al. found that the expression of several ASD candidate genes (e.g., Mief2, Eif3h, Cux1, and Atp8a1) in the hippocampus is dysregulated in response to prenatal BPA exposure and shows a sex-specific correlation with neuronal viability, neuritogenesis, and/or learning/memory [16]. The neuronal viability 
and neuronal density in the hippocampus and learning/memory are reduced only in the male offspring, while those in the females are not affected. In addition to the hippocampus, sex differences in the effects of prenatal BPA exposure on transcriptome profiles are also found in the hypothalamus and amygdala by other animal studies $[78,80]$.

The gene ontology analysis by IPA software revealed that the BPA-responsive genes in the offspring's prefrontal cortex were significantly associated with ASD and other disorders, including pervasive developmental disorder, schizophrenia spectrum disorder, movement disorders, and syndromic encephalopathy, all of which are known to be comorbid disorders of ASD [126-129]. A significant association of BPA-responsive genes and ASD was observed, both when male and female pups were combined into one group for each treatment and when each sex was analyzed separately. In addition to the results from the IPA analysis, the known ASD candidate genes available in the SFARI database were also over-represented in the lists of BPA-responsive genes. Moreover, DEGs in response to prenatal BPA exposure were also significantly associated with dysregulated genes in postmortem brain tissues from ASD cases. Strong associations were observed between BPA-responsive genes in the offspring's prefrontal cortex and DEGs in the frontal and temporal cortex of ASD cases, while DEGs in the occipital lobe and cerebellum of ASD cases showed little or no association. The association of BPA-responsive genes and ASD was also found in the hippocampus of pups prenatally exposed to BPA [15]. Taken together, these findings suggest that prenatal BPA exposure may increase the risk of ASD by affecting multiple brain regions of the offspring simultaneously, but changes in the transcriptome profiles and their association with ASD may be specific to certain areas of the brain.

The biological function and canonical pathway analysis by IPA also showed that BPA-responsive genes were involved in neurological functions and pathways known to be disrupted in ASD, including axonal guidance signaling [130], PTEN signaling [131], synaptic long-term depression and potentiation [132,133], and Wnt/calcium signaling [134]. In addition, DEGs in the prefrontal cortex of pups prenatally exposed to BPA were also associated with "proliferation of neuronal cells", "neuritogenesis", and "neurotransmission". Consistent with our findings, a recent study in mice reported that in utero BPA exposure suppresses the proliferation and differentiation of cortical neural progenitor cells during brain development. Moreover, synaptic formation and transmission in the cerebral cortex are also observed in mice prenatally exposed to BPA [135]. Interestingly, neural stem cells, neural progenitor cells, and neurons derived from ASD cases also exhibit abnormal proliferation, neurogenesis, and synaptogenesis [136,137]. Notably, BPA-responsive genes in the prefrontal cortex of male pups, but not female pups, are also significantly associated with androgen signaling and estrogen receptor signaling, both of which have been implicated in the male bias of ASD $[7,138,139]$.

The interactome network analysis unveiled the interactions among DEGs in response to BPA. Interestingly, the Lnpk, Kmt2a, and Neo1 genes are found to be the hub genes of DEGs in the prefrontal cortex of offspring. Lnpk or Lunapark, ER junction formation factor, is the gene responsible for shaping and stabilizing ER membrane proteins [140]. A study reported that three children who carried Lnpk gene mutations exhibited ASD-related neurodevelopmental defects, such as severe psychomotor delay, intellectual disability, hypotonia, and epilepsy [141]. Kmt2a, also known as the Mll gene, encodes a transcriptional coactivator that regulates the transcription of genes related to neurogenesis $[142,143]$. The loss of Kmt2a in forebrain neurons results in behavioral changes, such as increased anxiety, social behavior deficit, and impaired working memory, in an animal model [144,145]. In addition, de novo Kmt2a loss-of-function variants were found in people with neurodevelopmental disorders, including ASD [146]. Neo1, encoding neurogenin 1, is the hub gene of female DEGs. Neurogenin 1 is a receptor for Netrin-1, which is a protein involved in axon guidance signaling [147]. Moreover, Neo1 is expressed near the cortical plate during embryogenesis and plays an essential role in controlling neuronal migration in the embryonic brain [147,148]. Moreover, Neo1 controls NSC proliferation, neurogenesis, and synaptogenesis and is also involved in the expression of depressive-like behavior [149]. 
Genetic abnormalities in this gene, such as deletion, missense variants, and duplications, were observed in ASD cases [150]. The effects of prenatal BPA exposure on these genes in the offspring prefrontal cortex and their impacts on neurological functions and behaviors associated with ASD deserve further investigation.

To further investigate the effects of prenatal BPA exposure on genes associated with ASD in the prefrontal cortex, five ASD candidate genes (i.e., Ntng1, Auts2, Ankrd11, Dock4, and Syne1) from the SFARI database were selected for qRT-PCR analysis. When male and female pups were combined into one group for each treatment, the expression of Ntng1 was significantly reduced, whereas Auts2 was increased in the prefrontal cortex of pups prenatally exposed to BPA. The changes in the expression of Ankrd11, Dock4, and Syne1 were not significant. When each sex of pups was analyzed separately, Ntng1 was downregulated and Ankrd11 was upregulated in female pups in response to prenatal BPA exposure. Although Auts2 and Ankrd11 expression tended to increase in the male BPA group, no significant change was observed. Ntng1 or netrin G1 encodes a membrane protein that functions in axon and dendrite growth during brain development [151-153]. Netrin-G1 knockout mice show anxiety behaviors in the elevated plus-maze test and exhibited deficits in fear response behavior [154]. Missense mutations of NTNG1 were found in children with ASD [155]. The disruption of the NTNG1 gene from chromosome 1 abnormal rearrangement was detected in a female patient with Rett syndrome, a progressive neurodevelopmental disorder once characterized as a type of ASD [156]. Auts2 (autism susceptibility candidate 2 or activator of transcription and developmental regulator AUTS2) has been implicated in neurodevelopment due to its abundant expression in the developing brain, including the frontal cortex and the hippocampus $[157,158]$. Both copy number variation (CNV) duplications and deletions of AUTS2 were found in patients with developmental delay and ASD [159]. Several studies have also identified rare mutations in the Auts2 gene with ASD susceptibility [160-162]. Auts2 mutations cause abnormal cortical neuronal migration and neurite formation in the developing mouse brain [91]. The knockout or loss-of-function mutation of Auts2 causes microcephaly [161], neuron reduction [163], increased excitatory synapses, and ASD-like behaviors [164]. Ankrd11 is an ankyrin repeat domain-containing protein 11. Ankrd11 is expressed in precursor cells and neurons of the developing cortex [93]. Ankrd11 is associated with chromatin or transcription regulators that control the acetylation of histones and gene expression during the development of neurons. Several studies have shown associations of deletion or mutations of the Ankrd11 gene with ASD $[165,166]$. Duplication involving ANKRD11 was found in patients with KBG syndrome, which exhibits severe developmental delay and intellectual disability $[167,168]$. The downregulation of Ankrd11 in developing murine or human cortical neural precursor cells causes decreased neural proliferation, reduced neurogenesis, and abnormal neuronal positioning [93]. Moreover, an animal model with downregulated Ankrd11 in the brain displays abnormal locomotion activity, social interaction deficits, and repetitive behavior, all of which are ASD-related behaviors [93]. The role of these genes, specifically the downregulation of Ntng1 and the upregulation of Auts2 and Ankrd11, in the context of ASD and the underlying molecular mechanisms through which BPA regulates the expression of these genes should be further studied.

BPA can bind to several nuclear receptor proteins, including AR, ESR1, THRA, ERRG, and PPARG, which may affect downstream signaling and dysregulate cellular functions $[96-98,169]$. Several nuclear receptors and other types of transcription factors are associated with ASD [88,103,170-172]. In this study, we found that as many as 96 human transcription factors have been associated with ASD and listed in the SFARI database as ASD candidate genes. Among those, the targets of 34 transcription factors were available in the Harmonizome database. Interestingly, the targets of as many as 25 out of 34 transcription factors were significantly over-represented in the lists of BPA-responsive genes, suggesting that these transcription factors may be responsible for altered transcriptome profiles in the prefrontal cortex of pups prenatally exposed to BPA. AR, ESR1, and THRA, which are known to be BPA targets, and were also identified as significant 
transcription factors in this study. The association between BPA-responsive genes and the targets of RORA was further confirmed using the list of RORA1 targets in the human neuronal cell line SH-SY5Y identified by our previous study [103]. RORA1 targets were significantly enriched in the lists of BPA-responsive genes in the prefrontal cortex of male pups and female pups when compared to age/sex-matched control pups, suggesting that RORA1 is involved in the effects of BPA on dysregulation of genes in the offspring prefrontal cortex. ERRG and PPARG were not listed as ASD candidate genes in the SFARI database and thus were not used for hypergeometric analysis and molecular docking in this study. In addition to these transcription factors, we identified transcription factors, RORA, SOX5, TCF4, and YY1, as novel targets of BPA by molecular docking analysis. Although these transcription factors were obtained from human databases, all transcription factors are also conserved in rats according to the NCBI HomoloGene database (https:/ /www.ncbi.nlm.nih.gov/homologene, accessed on 25 May 2020). It is noteworthy that Ntng1 is known to be a transcriptional target of RORA [103], TCF4 [173], and YY1 [174]. Auts2 is a transcriptional target of AR [175], SOX5 [101,102], TCF4 [173], and YY1 [174]. Ankrd11 is a transcriptional target of TCF4 [173] and YY1 [174]. Both Dock4 and Syne1 are transcriptional targets of ESR1 [101,102] and YY1 [174]. Moreover, AR, ESR1, and RORA have been implicated in the sex bias of ASD $[86,87,139]$. Our previous study showed that male and female hormones differentially regulated the expression of RORA in the human neuronal cell line SH-SY5Y through AR and ESR1, respectively. Moreover, we found that RORA transcriptionally regulated aromatase and that the protein levels of RORA and aromatase were significantly reduced in the frontal cortex of people with ASD $[86,176]$. The direct interaction between BPA and these transcription factors, protein, and RNA expression of all ASD-related transcription factors, as well as its effects on the signaling mediated by these transcription factors, deserve further investigation.

\section{Materials and Methods}

\subsection{Animal Husbandry and Treatment}

Eight-week-old male and female Wistar Furth rats were obtained from the National Laboratory Animal Center (NLAC), Thailand. All animals were housed at the Chulalongkorn University Laboratory Animal Center (CULAC) under standard temperature $\left(21 \pm 1{ }^{\circ} \mathrm{C}\right)$ and humidity $(30-70 \%)$ conditions in a 12-h light/dark cycle with food and RO-UV water available ad libitum. After mating, female rats (GD1; $n=6)$ were divided into two groups, i.e., the BPA treatment group and the control group. The weight of each rat was measured daily and used to calculate the amount of BPA or vehicle control needed to treat each rat. Animal treatment was performed as previously described [15]. For BPA treatment, BPA (Sigma-Aldrich, St. Louis, MO, USA) was dissolved in absolute ethanol (Merck Millipore, Burlington, MA, USA) to a final concentration of $250 \mathrm{mg} / \mathrm{mL}$ to make a stock BPA solution. Then, the stock solution was further diluted with corn oil to a final concentration of $5000 \mu \mathrm{g} / \mathrm{kg} \cdot$ maternal BW of BPA to treat each rat. The vehicle control treatment was prepared by mixing absolute ethanol with corn oil in amounts equivalent to those used for preparing BPA. After mating, female rats were intragastrically administered by either BPA or vehicle control from GD1 until parturition. To prevent cross-contamination of the treatment conditions, the rats in the BPA and control groups were raised separately in individually ventilated cages in a biohazard containment housing system. Separate sets of stainless-steel needles and all consumable products were used for oral gavage. All reusable materials were cleaned with ethanol and rinsed with copious amounts of Milli-Q deionized water before use. All experimental procedures were approved by the Chulalongkorn University Animal Care and Use Committee (animal use protocols numbers: 1673007, 1773011, and 2073011), Chulalongkorn University.

\subsection{Tissue Dissection}

Male and female neonatal rat pups from independent litters ( $n=3$ pups/sex/treatment) were used for transcriptome profiling and qRT-PCR analysis. Prefrontal cortex tissues were 
identified and dissected under a Nikon SMZ18 Stereo Microscope (Nikon, Tokyo, Japan) as previously described with slight modifications [177]. According to the protocol by Guo et al. [178], rat pups (postnatal days (PNDs) 1-2) were deeply anesthetized by intraperitoneal injection of $100 \mathrm{mg} / \mathrm{kg}$. BW sodium pentobarbital and euthanized by decapitation. The brain was quickly and carefully removed from the skull and placed in a prechilled cell culture dish containing ice-cold, freshly prepared $1 \times$ HBSS (Invitrogen, Waltham, MA, USA) containing $30 \mathrm{mM}$ glucose (Sigma-Aldrich, Saint Louis, MO, USA), 2 mM HEPES (GE Healthcare Bio-Sciences, Piscataway, NJ, USA), and $26 \mathrm{mM} \mathrm{NaHCO}_{3}$ (Sigma-Aldrich, Saint Louis, MO, USA). The meninges were completely removed. The prefrontal cortex was dissected and immediately placed in a tube with RNA stabilization reagent (RNAlater) (Ambion, Austin, TX, USA) and stored at $-80{ }^{\circ} \mathrm{C}$ according to the manufacturer's protocol until use.

\subsection{RNA Isolation}

Total RNA was extracted and purified using the mirVana ${ }^{\mathrm{TM}}$ miRNA Isolation Kit (Thermo Fisher Scientific, Waltham, MA, USA) according to the manufacturer's protocol. Briefly, prefrontal cortex tissues were lysed in a denaturing lysis buffer, which stabilized RNA and inactivated RNases. Prefrontal cortex tissue lysates were then subjected to acid-phenol:chloroform extraction to purify RNA and remove DNA. Ethanol was then added to the samples and passed through a filter cartridge containing a glass-fiber filter that immobilized the RNA. The filter was then washed three times, and finally, total RNA was eluted with a low ionic-strength solution. The purity of total RNA was assessed using a NanoDrop spectrophotometer (Thermo Fisher Scientific, Waltham, MA, USA) and quantified by using Invitrogen Qubit 2.0 Fluorometer (Thermo Fisher Scientific, Waltham, MA, USA). An Agilent 2100 BioAnalyzer (Agilent Technologies, Santa Clara, CA, USA) was used to determine RNA integrity. The results from the bioanalyzer were presented as the 28S:18S rRNA ratio and the RNA integrity number (RIN). The 28S:18S rRNA ratio was greater than 1.0, and the RIN was greater than 7.0 for all RNA samples.

\subsection{Transcriptome Profiling Analysis}

To identify DEGs in response to maternal BPA exposure, a transcriptome profiling analysis of total RNA isolated from the prefrontal cortex of neonatal rats from six independent litters prenatally exposed to BPA or vehicle control was performed by BGI Genomics Co., Ltd., China, using the Illumina HiSeq 4000 next-generation sequencing platform with $4 \mathrm{G}$ reads (Illumina, San Diego, CA, USA) as previously described [15]. For RNA-seq analysis, RNA quality requirements were total RNA of $\geq 200 \mathrm{ng}$, RNA concentrations of $\geq 20 \mathrm{ng} / \mu \mathrm{L}$, RINs of $\geq 7.0$, and $28 \mathrm{~S} / 18 \mathrm{~S}$ rRNA ratios of $\geq 1.0$. Briefly, total RNA was treated with DNase I to remove DNA, and oligo(dT) treatment was used for mRNA isolation. Next, mRNA samples were fragmented by adding a fragmentation buffer, and reverse transcription was performed using mRNA fragments as templates. Short fragments were purified and resolved with an EB buffer for end repair and single nucleotide adenine addition. After that, the short fragments were connected with adapters, and suitable fragments were selected for PCR amplification. For quality control, an Agilent 2100 Bioanalyzer (Agilent Technologies, Santa Clara, CA, USA) and an ABI StepOnePlus Real-Time PCR System (Applied Biosystems, Waltham, MA, USA) were used in the quantification and qualification of the sample library. The library was sequenced using Illumina HiSeq 4000 (Illumina, San Diego, CA, USA). Subsequently, sequencing reads were filtered and subjected to quality control. Clean reads in a FASTQ file were mapped to the rat reference genome Rnor_6.0 (RefSeq ID: 1174938) using Bowtie 2 [15,179], and gene expression levels were then calculated using RSEM [180]. The transcriptome profiles between the BPA and the control groups were compared using a Poisson distribution. Comparisons were performed with all male and female pups with the same treatment condition combined into one group and separately for each sex. $p$-values were calculated using a Poisson distribution method. DEGs with a $p$-value of $<0.05$ and an FDR of $<0.05$ were considered statistically significant. 


\section{5. $q R T-P C R$ Analysis}

qRT-PCR analysis was performed to confirm the expression of five selected ASD candidate genes that were differentially expressed in response to prenatal BPA exposure. Reverse transcription was performed using a RevertAid First Strand cDNA Synthesis Kit (Thermo Scientific, Waltham, MA, USA) following the manufacturer's protocol. Briefly, a total of $0.5 \mu \mathrm{g}$ total RNA were mixed with $0.2 \mu \mathrm{g}$ random hexamer primer and incubated at $65^{\circ} \mathrm{C}$ for $5 \mathrm{~min}$. After that, cDNA synthesis reagents consisting of $4 \mu \mathrm{L}$ of a $5 \mathrm{X}$ Reaction Buffer, $1 \mu \mathrm{L}$ of a RiboLock RNase Inhibitor $(20 \mathrm{U} / \mu \mathrm{L}), 2 \mu \mathrm{L}$ of $10 \mathrm{mM}$ dNTP Mix, and $1 \mu \mathrm{L}$ of RevertAid M-MuLV Reverse Transcriptase $(200 \mathrm{U} / \mu \mathrm{L})$ were added to the mixture and brought the total volume to $20 \mu \mathrm{L}$. Reverse transcription was performed by incubation at $25^{\circ} \mathrm{C}$ for $5 \mathrm{~min}$, followed by $42{ }^{\circ} \mathrm{C}$ for $60 \mathrm{~min}$. The reaction was terminated by heating the solution to $70{ }^{\circ} \mathrm{C}$ for $5 \mathrm{~min}$.

qPCR analysis was performed using AccuPower ${ }^{\circledR} 2 X$ GreenStar $^{\mathrm{TM}}$ qPCR MasterMix (Bioneer, Daejeon, South Korea) according to the manufacturer's instructions. Briefly, $1 \mu \mathrm{L}$ of cDNA was mixed with 2X Greenstar Master Mix, a forward primer, a reverse primer, and nuclease-free water. Each sample was prepared in triplicate reactions. The reaction was then incubated in a Bio-Rad CFX Connect Real-Time PCR Detection System (Bio-Rad, Hercules, CA, USA). The PCR conditions were set as follows: an initial denaturing step at $95^{\circ} \mathrm{C}$ for $15 \mathrm{~min}, 40$ cycles of $95^{\circ} \mathrm{C}$ for $10 \mathrm{~s}$ per cycle, and $30 \mathrm{~s}$ at $55^{\circ} \mathrm{C}$ for annealing/extension. Melting curve analysis was set at 65 to $95^{\circ} \mathrm{C}$ for product confirmation. The expression levels were calculated by the $2^{-\Delta \Delta C t}$ method using the $18 \mathrm{~S}$ ribosomal RNA (Rn18s) gene as an endogenous control. The primers used in this study were designed using the UCSC Genome Browser (https:/ / genome.ucsc.edu/, accessed on 17 May 2019) [181], Ensembl (https:/ / asia.ensembl.org/index.html, accessed on 17 May 2019) [182], and Primer3 software (http:/ / bioinfo.ut.ee/primer3-0.4.0/, accessed on 17 May 2019) [183-185]. Forward and reverse primers were designed for rat Auts2, Ankrd11, Ntng1, Dock4, Syne1, and Rn18s. The sequences of the qPCR primers are shown in Table S15.

\subsection{Prediction of Biological Functions, Disorders, Canonical Pathways, and Interactome Networks} Associated with DEGs

Biological functions, disorders, canonical pathways, and interactome networks associated with DEGs were predicted using IPA (QIAGEN Inc., https: / / www.qiagenbioinformatics. com/products/ingenuity-pathway-analysis/, accessed on 25 May 2020) [89]. The list of DEGs overlapped with the list of genes experimentally validated to be associated with each function/disorder/canonical pathway in Ingenuity's Knowledge Base database. Fisher's exact test was then performed to calculate $p$-values, and a $p$-value of $<0.05$ was considered statistically significant.

\subsection{Transcriptome Profiling Analysis of Postmortem Brain Tissues from ASD and Unaffected Individuals}

To identify significantly DEGs in the brains of ASD cases, the transcriptome profiling data of postmortem brain tissues from ASD cases and typically developing people were obtained from the NCBI Gene Expression Omnibus (GEO) repository (http:/ / www.ncbi. nlm.nih.gov/gds, accessed on 2 May 2020) [186] in a search performed on 2 May 2020, using "postmortem brain and autism" as a keyword. The details of the transcriptome profiling datasets used in this study are shown in Table S9. Transcriptome profiling data from each study were then analyzed separately according to the brain region by using Multiple Experiment Viewer (MeV) software (http:/ / mev.tm4.org/86, accessed on 9 May 2020) [187]. To identify DEGs in ASD brain tissues, two-tailed t-tests with adjusted Bonferroni correction were performed. Then, the lists of DEGs from postmortem brain tissues overlapped with the list of BPA-responsive DEGs in our study. The significant associations between DEGs in the brains of ASD cases and BPA-responsive genes were determined by using the hypergeometric distribution calculator program in the Keisan Online Calculator package (http:/ / keisan.casio.com/exec/system/1180573201, accessed 
on 18 May 2020). Four parameters in the hypergeometric distribution calculator were the number of overlapping genes, the number of BPA-responsive genes, the number of DEGs from the postmortem brain tissues that were detected in the rat prefrontal cortex, and the number of genes detectable in the prefrontal cortex by RNA-seq analysis. A hypergeometric $p$-value of $<0.05$ was considered statistically significant.

\subsection{Molecular Docking}

To determine whether BPA can directly interact with transcription factors of which the target genes are associated with BPA-responsive genes. BPA structure was obtained from PubChem Open Chemistry Database (NIH, USA, https://pubchem.ncbi.nlm.nih.gov, accessed on 25 May 2020), and protein structures were obtained from RCSB Protein Data Bank (PDB) (https: / / www.rcsb.org/, accessed on 25 May 2020). The criteria for choosing transcription factor structures from the PDB database for docking were as follows: (i) the resolution was less than 3 Angstrom; and (ii) the structure was discovered by X-ray diffraction. For transcription factors of which the structures are not available in the PDB database, the structures were obtained from the Alphafold Protein Structure Database (https://alphafold.ebi.ac.uk/, accessed on 25 May 2020) [188]. The Discovery Studio Visualizer program (BIOVIA, San Diego, CA, USA, http:/ / www.3dsbiovia.com/products / collaborative-science/biovia-discovery-studio/visualization-download.php, accessed on 30 May 2020) was used to remove crystal water molecules and to add partial charges to each atom. Then, the molecular docking between BPA, known ligands, and transcription factors was performed using Autodock 4 and AutodockTools 4 [189]. The binding abilities between BPA or known ligands and each transcription factor were evaluated and were shown as Gibbs free energy $(\Delta G)$. For each pair of BPA/ligands and a transcription factor, the binding free energy was averaged from three independent runs.

\section{Conclusions}

Our transcriptomic profiling analysis revealed that in utero BPA exposure caused the sex-dependent dysregulation of transcriptome-interactome profiles in the prefrontal cortex of neonatal rat pups. BPA-responsive genes were associated with ASD and related neurological functions and pathways. Moreover, known ASD candidate genes and genes disrupted in the brains of ASD cases were significantly enriched in the lists of BPA-responsive genes. In addition, BPA-responsive genes are known targets of several transcription factors, including AR, ESR1, and RORA, which have been linked to the pathobiology or sex bias of ASD. Molecular docking predicted that BPA may directly interact with these transcription factors, many of which are novel targets for BPA, including RORA, SOX5, TCF4, and YY1. Taken together, these findings suggest that in utero BPA exposure may increase the risk of ASD by impacting ASD-related genes in the offspring's prefrontal cortex, possibly through sex-specific transcription factors associated with the disorder. A better understanding of prenatal BPA exposure effects and the underlying molecular mechanisms may lead to increased awareness and development of molecular targets for treatment in the future.

Supplementary Materials: The following are available online at https:/ / www.mdpi.com/article/10 $.3390 /$ ijms222413201/s1.

Author Contributions: Conceptualization, T.S.; data curation, S.K., S.T. and T.S.; formal analysis, S.K., S.T., P.P. and T.S.; funding acquisition, T.S.; investigation, S.K., S.T., P.P. and T.S.; methodology, S.K., S.T. and T.S.; project administration, T.S.; resources, V.W.H. and T.S.; software, V.W.H.; supervision, D.J., T.K., N.O. and T.S.; validation, S.K. and T.S.; visualization, S.K. and P.P.; writing-original draft, S.K. and T.S.; writing-review and editing, D.J., V.W.H., T.K., N.O. and T.S. All authors have read and agreed to the published version of the manuscript.

Funding: This study was supported by Fundamental Fund, Chulalongkorn University (FRB65_hea(80)_175_37_05), Faculty of Allied Health Sciences Research Fund, Chulalongkorn University (AHS-CU 61004), and a Ratchadapisek Somphot Fund for Supporting Research Unit, Chulalongkorn University (GRU 6300437001-1, GRU_64_033_37_004) to T.S. The transcriptome profiling 
was partly supported by a grant from the National Research University Project, Office of Higher Education Commission (NRU59-031-HR) to T.S. This research and innovation activity is also funded by National Research Council of Thailand (NRCT) to S.T. S.K. was financially supported by "The 90th Anniversary Chulalongkorn University Fund (Ratchadaphiseksomphot Endowment Fund: GCUGR1125623067D-67)”, "The 100th Anniversary Chulalongkorn University Fund for Doctoral Scholarship", and "The Overseas Research Experience Scholarship for Graduate Students from the Graduate School, Chulalongkorn University". S.T. received the Royal Golden Jubilee Ph.D. Programme Scholarship (grant no. PHD/0029/2561) from the Thailand Research Fund and National Research Council of Thailand, "The 90th Anniversary Chulalongkorn University Fund (Ratchadaphiseksomphot Endowment Fund: GCUGR1125632108D-108)”, Graduate School, Chulalongkorn University. P.P. was financially supported by "The 100th Anniversary Chulalongkorn University Fund for Doctoral Scholarship". Animal husbandry and housing were financially supported by Chulalongkorn University Laboratory Animal Center (CULAC) Grant (Animal Use Protocol No. 2073011) to T.S. and Kasidit Kasitipradit.

Institutional Review Board Statement: All animal experiment procedures were approved by the Chulalongkorn University Animal Care and Use Committee (animal use protocol numbers: 1673007, 1773011, and 2073011), Chulalongkorn University.

Informed Consent Statement: Not applicable.

Data Availability Statement: The transcriptome profiling data used in this study have been published in the NCBI GEO DataSet database (GSE28475, GSE28521, and GSE38322). The RNA-seq data will be made publicly available in the GEO upon the acceptance of this manuscript for publication.

Acknowledgments: S.K., S.T., and P.P. are graduate students in the Ph.D. Program in Clinical Biochemistry and Molecular Medicine, Department of Clinical Chemistry, Faculty of Allied Health Sciences, Chulalongkorn University. We wish to acknowledge Suwanakiet Sawangkoon, Anusak Kijtawornrat, Nitira Anakkul, Choopet Nitsakulthong, Sornsawan Chumjai, Saifon Sreechomphoe, and Phanupong Dungkhokkruat from the Chulalongkorn University Laboratory Animal Center for their assistance with the ethical approval process and training S.K., S.T., P.P., and T.S. in the proper care and use of laboratory animals. We thank Chanin Sillapachaiyaporn for his help in training the molecular docking program and Thanit Saeliw for his assistance in qRT-PCR analysis.

Conflicts of Interest: The authors declare no conflict of interest.

\section{References}

1. American Psychiatric Association. Diagnostic and Statistical Manual of Mental Disorders (DSM-5®); American Psychiatric Pub: Washington, DC, USA, 2013.

2. Maenner, M.J.; Shaw, K.A.; Baio, J.; Washington, A.; Patrick, M.; DiRienzo, M.; Christensen, D.L.; Wiggins, L.D.; Pettygrove, S.; Andrews, J.G.; et al. Prevalence of autism spectrum disorder among children aged 8 years-Autism and developmental disabilities monitoring network, 11 sites, United States, 2016. MMWR Surveill. Summ. 2020, 69, 1-12. [CrossRef] [PubMed]

3. Huguet, G.; Ey, E.; Bourgeron, T. The genetic landscapes of autism spectrum disorders. Annu. Rev. Genom. Hum. Genet. 2013, 14, 191-213. [CrossRef] [PubMed]

4. Tordjman, S.; Somogyi, E.; Coulon, N.; Kermarrec, S.; Cohen, D.; Bronsard, G.; Bonnot, O.; Weismann-Arcache, C.; Botbol, M.; Lauth, B.; et al. Gene $\times$ Environment Interactions in Autism Spectrum Disorders: Role of Epigenetic Mechanisms. Front. Psychiatry 2014, 5, 53. [CrossRef] [PubMed]

5. Moosa, A.; Shu, H.; Sarachana, T.; Hu, V.W. Are endocrine disrupting compounds environmental risk factors for autism spectrum disorder? Horm. Behav. 2018, 101, 13-21. [CrossRef]

6. Pichitpunpong, C.; Thongkorn, S.; Kanlayaprasit, S.; Yuwattana, W.; Plaingam, W.; Sangsuthum, S.; Aizat, W.M.; Baharum, S.N.; Tencomnao, T.; Hu, V.W.; et al. Phenotypic subgrouping and multi-omics analyses reveal reduced diazepam-binding inhibitor (DBI) protein levels in autism spectrum disorder with severe language impairment. PLoS ONE 2019, 14, e0214198. [CrossRef]

7. Saeliw, T.; Tangsuwansri, C.; Thongkorn, S.; Chonchaiya, W.; Suphapeetiporn, K.; Mutirangura, A.; Tencomnao, T.; Hu, V.W.; Sarachana, T. Integrated genome-wide Alu methylation and transcriptome profiling analyses reveal novel epigenetic regulatory networks associated with autism spectrum disorder. Mol. Autism 2018, 9, 27. [CrossRef] [PubMed]

8. Tangsuwansri, C.; Saeliw, T.; Thongkorn, S.; Chonchaiya, W.; Suphapeetiporn, K.; Mutirangura, A.; Tencomnao, T.; Hu, V.W.; Sarachana, T. Investigation of epigenetic regulatory networks associated with autism spectrum disorder (ASD) by integrated global LINE-1 methylation and gene expression profiling analyses. PLoS ONE 2018, 13, e0201071. [CrossRef] [PubMed]

9. Bellanger, M.; Demeneix, B.; Grandjean, P.; Zoeller, R.T.; Trasande, L. Neurobehavioral deficits, diseases, and associated costs of exposure to endocrine-disrupting chemicals in the European Union. J. Clin. Endocrinol. Metab. 2015, 100, 1256-1266. [CrossRef] [PubMed] 
10. Long, M.; Ghisari, M.; Kjeldsen, L.; Wielsøe, M.; Nørgaard-Pedersen, B.; Mortensen, E.L.; Abdallah, M.W.; Bonefeld-Jørgensen, E.C. Autism spectrum disorders, endocrine disrupting compounds, and heavy metals in amniotic fluid: A case-control study. Mol. Autism 2019, 10, 1-19. [CrossRef] [PubMed]

11. Adams, J.B.; Romdalvik, J.; Ramanujam, V.M.S.; Legator, M.S. Mercury, lead, and zinc in baby teeth of children with autism versus controls. J. Toxicol. Environ. Health Part A 2007, 70, 1046-1051. [CrossRef] [PubMed]

12. Adams, J.B.; Audhya, T.; McDonough-Means, S.; Rubin, R.A.; Quig, D.; Geis, E.; Gehn, E.; Loresto, M.; Mitchell, J.; Atwood, S.; et al. Toxicological status of children with autism vs. neurotypical children and the association with autism severity. Biol. Trace Elem. Res. 2013, 151, 171-180. [CrossRef] [PubMed]

13. Khalil, N.; Kaur, B.; Lawson, A.; Ebert, J.; Nahhas, R.J.E.D. Secondhand smoke exposure is associated with autism spectrum disorder in US males but not in females: Results from the National Survey on Children's Health. Environ. Dis. $2018,3,8$. [CrossRef]

14. Becerra, T.A.; Wilhelm, M.; Olsen, J.; Cockburn, M.; Ritz, B. Ambient air pollution and autism in Los Angeles County, California. Environ. Health Perspect. 2013, 121, 380-386. [CrossRef]

15. Thongkorn, S.; Kanlayaprasit, S.; Jindatip, D.; Tencomnao, T.; Hu, V.W.; Sarachana, T. Sex differences in the effects of prenatal bisphenol a exposure on genes associated with autism spectrum disorder in the hippocampus. Sci. Rep. 2019, 9, 3038. [CrossRef] [PubMed]

16. Thongkorn, S.; Kanlayaprasit, S.; Panjabud, P.; Saeliw, T.; Jantheang, T.; Kasitipradit, K.; Sarobol, S.; Jindatip, D.; Hu, V.W.; Tencomnao, T.; et al. Sex differences in the effects of prenatal bisphenol A exposure on autism-related genes and their relationships with the hippocampus functions. Sci. Rep. 2021, 11, 1241. [CrossRef]

17. Panesar, H.K.; Kennedy, C.L.; Keil Stietz, K.P.; Lein, P.J. Polychlorinated Biphenyls (PCBs): Risk factors for autism spectrum disorder? Toxics 2020, 8, 70. [CrossRef]

18. Kim, J.I.; Lee, J.; Lee, K.-S.; Lee, Y.A.; Shin, C.H.; Hong, Y.-C.; Kim, B.-N.; Lim, Y.-H. Association of phthalate exposure with autistic traits in children. Environ. Int. 2021, 157, 106775. [CrossRef]

19. Hertz-Picciotto, I. Polybrominated diphenyl ethers (PBDES) in relation to autism and developmental delay. Epidemiology 2007, 18, S192. [CrossRef]

20. Rist, S.; Carney Almroth, B.; Hartmann, N.B.; Karlsson, T.M. A critical perspective on early communications concerning human health aspects of microplastics. Sci. Total Environ. 2018, 626, 720-726. [CrossRef]

21. Campanale, C.; Massarelli, C.; Savino, I.; Locaputo, V.; Uricchio, V.F. A detailed review study on potential effects of microplastics and additives of concern on human health. Int. J. Environ. Res. Public Health 2020, 17, 1212. [CrossRef]

22. Brotons, J.A.; Olea-Serrano, M.F.; Villalobos, M.; Pedraza, V.; Olea, N. Xenoestrogens released from lacquer coatings in food cans. Environ. Health Perspect. 1995, 103, 608-612. [CrossRef] [PubMed]

23. Habib, C.M.; Kugel, G. Estrogenicity of resin-based composites and sealants in dentistry. Environ. Health Perspect. 1996, $104,808$. [CrossRef]

24. Krishnan, A.V.; Stathis, P.; Permuth, S.F.; Tokes, L.; Feldman, D. Bisphenol-A: An estrogenic substance is released from polycarbonate flasks during autoclaving. Endocrinology 1993, 132, 2279-2286. [CrossRef] [PubMed]

25. Konieczna, A.; Rutkowska, A.; Rachoń, D. Health risk of exposure to Bisphenol A (BPA). Roczniki Państwowego Zakładu Higieny 2015, 66, 5-11.

26. Thayer, K.A.; Doerge, D.R.; Hunt, D.; Schurman, S.H.; Twaddle, N.C.; Churchwell, M.I.; Garantziotis, S.; Kissling, G.E.; Easterling, M.R.; Bucher, J.R.; et al. Pharmacokinetics of bisphenol A in humans following a single oral administration. Environ. Int. 2015, 83, 107-115. [CrossRef]

27. Welshons, W.V.; Nagel, S.C.; vom Saal, F.S. Large effects from small exposures. III. Endocrine Mechanisms mediating effects of bisphenol a at levels of human exposure. Endocrinology 2006, 147, s56-s69. [CrossRef]

28. Vandenberg, L.N.; Chahoud, I.; Heindel, J.J.; Padmanabhan, V.; Paumgartten, F.J.R.; Schoenfelder, G. Urinary, circulating, and tissue biomonitoring studies indicate widespread exposure to Bisphenol A. Environ. Health Perspect. 2010, 118, 1055-1070. [CrossRef]

29. Braniste, V.; Audebert, M.; Zalko, D.; Houdeau, E. Bisphenol A in the gut: Another break in the wall. In Multi-System Endocrine Disruption; Bourguignon, J.-P., Jégou, B., Kerdelhué, B., Toppari, J., Christen, Y., Eds.; Springer: Berlin/Heidelberg, Germany, 2011; pp. 127-144.

30. Nishikawa, M.; Iwano, H.; Yanagisawa, R.; Koike, N.; Inoue, H.; Yokota, H. Placental transfer of conjugated Bisphenol A and subsequent reactivation in the rat fetus. Environ. Health Perspect. 2010, 118, 1196-1203. [CrossRef]

31. Balakrishnan, B.; Henare, K.; Thorstensen, E.B.; Ponnampalam, A.P.; Mitchell, M.D. Transfer of bisphenol A across the human placenta. Am. J. Obstet. Gynecol. 2010, 202, 393.e391-393.e397. [CrossRef] [PubMed]

32. Engdahl, E.; van Schijndel, M.D.M.; Voulgaris, D.; Di Criscio, M.; Ramsbottom, K.A.; Rigden, D.J.; Herland, A.; Rüegg, J. Bisphenol A inhibits the transporter function of the blood-brain barrier by directly interacting with the $\mathrm{ABC}$ transporter breast cancer resistance protein (BCRP). Int. J. Mol. Sci. 2021, 22, 5534. [CrossRef]

33. Sun, Y.; Nakashima, M.N.; Takahashi, M.; Kuroda, N.; Nakashima, K. Determination of Bisphenol A in rat brain by microdialysis and column switching high-performance liquid chromatography with fluorescence detection. Biomed. Chromatogr. 2002, 16, 319-326. [CrossRef] [PubMed] 
34. Domoradzki, J.Y.; Pottenger, L.H.; Thornton, C.M.; Hansen, S.C.; Card, T.L.; Markham, D.A.; Dryzga, M.D.; Shiotsuka, R.N.; Waechter, J.M., Jr. Metabolism and pharmacokinetics of Bisphenol A (BPA) and the embryo-fetal distribution of BPA and BPA-monoglucuronide in CD sprague-dawley rats at three gestational stages. Toxicol. Sci. 2003, 76, 21-34. [CrossRef] [PubMed]

35. Vandenberg, L.N.; Hauser, R.; Marcus, M.; Olea, N.; Welshons, W.V. Human exposure to bisphenol A (BPA). Reprod. Toxicol. 2007, 24, 139-177. [CrossRef]

36. Liao, C.; Kannan, K. Widespread occurrence of Bisphenol A in paper and paper products: Implications for human exposure. Environ. Sci. Technol. 2011, 45, 9372-9379. [CrossRef] [PubMed]

37. Calafat, A.M.; Ye, X.; Wong, L.-Y.; Reidy, J.A.; Needham, L.L. Exposure of the US population to bisphenol A and 4-tertiaryoctylphenol: 2003-2004. Environ. Health Perspect. 2008, 116, 39-44. [CrossRef]

38. Hansen, J.B.; Bilenberg, N.; Timmermann, C.A.G.; Jensen, R.C.; Frederiksen, H.; Andersson, A.-M.; Kyhl, H.B.; Jensen, T.K. Prenatal exposure to Bisphenol A and autistic- and ADHD-related symptoms in children aged 2 and5 years from the Odense Child Cohort. Environ. Health 2021, 20, 24. [CrossRef]

39. Liu, J.; Li, J.; Wu, Y.; Zhao, Y.; Luo, F.; Li, S.; Yang, L.; Moez, E.K.; Dinu, I.; Martin, J.W. Bisphenol A metabolites and Bisphenol S in paired maternal and cord serum. Environ. Sci. Technol. 2017, 51, 2456-2463. [CrossRef] [PubMed]

40. Edlow, A.G.; Chen, M.; Smith, N.A.; Lu, C.; McElrath, T.F. Fetal bisphenol A exposure: Concentration of conjugated and unconjugated bisphenol A in amniotic fluid in the second and third trimesters. Reprod. Toxicol. 2012, 34, 1-7. [CrossRef] [PubMed]

41. Schönfelder, G.; Wittfoht, W.; Hopp, H.; Talsness, C.E.; Paul, M.; Chahoud, I. Parent Bisphenol A accumulation in the human maternal-fetal-placental unit. Environ. Health Perspect. 2002, 110, A703-A707. [CrossRef] [PubMed]

42. Todaka, E.; Mori, C. Necessity to establish new risk assessment and risk communication for human fetal exposure to multiple endocrine disruptors in Japan. Congenit. Anom. 2002, 42, 87-93. [CrossRef] [PubMed]

43. Kuruto-Niwa, R.; Tateoka, Y.; Usuki, Y.; Nozawa, R. Measurement of Bisphenol A concentrations in human colostrum. Chemosphere 2007, 66, 1160-1164. [CrossRef] [PubMed]

44. Ye, X.; Kuklenyik, Z.; Needham, L.L.; Calafat, A.M. Measuring environmental phenols and chlorinated organic chemicals in breast milk using automated on-line column-switching-high performance liquid chromatography-isotope dilution tandem mass spectrometry. J. Chromatogr. B 2006, 831, 110-115. [CrossRef]

45. Kondolot, M.; Ozmert, E.N.; Asc1, A.; Erkekoglu, P.; Oztop, D.B.; Gumus, H.; Kocer-Gumusel, B.; Yurdakok, K. Plasma phthalate and bisphenol a levels and oxidant-antioxidant status in autistic children. Environ. Toxicol. Pharmacol. 2016, 43, 149-158. [CrossRef] [PubMed]

46. Kardas, F.; Bayram, A.K.; Demirci, E.; Akin, L.; Ozmen, S.; Kendirci, M.; Canpolat, M.; Oztop, D.B.; Narin, F.; Gumus, H.; et al. Increased serum phthalates (MEHP, DEHP) and Bisphenol A concentrations in children with autism spectrum disorder: The role of endocrine disruptors in autism etiopathogenesis. J. Child. Neurol. 2016, 31, 629-635. [CrossRef] [PubMed]

47. Stein, T.P.; Schluter, M.D.; Steer, R.A.; Guo, L.; Ming, X. Bisphenol A exposure in children with autism spectrum disorders. Autism Res. 2015, 8, 272-283. [CrossRef] [PubMed]

48. United States Food and Drug Administration. 2014 Updated Safety Assessment of Bisphenol A (BPA) for Use in Food Contact Applications; The United States Food and Drug Administration: Silver Spring, MD, USA, 2014.

49. Prins, G.S.; Hu, W.-Y.; Xie, L.; Shi, G.-B.; Hu, D.-P.; Birch, L.; Bosland, M.C. Evaluation of Bisphenol A (BPA) exposures on prostate stem cell homeostasis and prostate cancer risk in the NCTR-sprague-dawley rat: An NIEHS/FDA CLARITY-BPA Consortium Study. Environ. Health Perspect. 2018, 126, 117001. [CrossRef] [PubMed]

50. Lejonklou, M.H.; Dunder, L.; Bladin, E.; Pettersson, V.; Rönn, M.; Lind, L.; Waldén, T.B.; Lind, P.M. Effects of low-dose developmental Bisphenol A exposure on metabolic parameters and gene expression in male and female Fischer 344 rat offspring. Environ. Health Perspect. 2017, 125, 067018. [CrossRef]

51. Fujiwara, Y.; Miyazaki, W.; Koibuchi, N.; Katoh, T. The effects of low-dose Bisphenol A and Bisphenol F on neural differentiation of a fetal brain-derived neural progenitor cell line. Front. Endocrinol. 2018, 9, 34. [CrossRef] [PubMed]

52. Sekizawa, J. Low-dose effects of bisphenol A: A serious threat to human health? J. Toxicol. Sci. 2008, 33, 389-403. [CrossRef]

53. Vandenberg, L.N.; Ehrlich, S.; Belcher, S.M.; Ben-Jonathan, N.; Dolinoy, D.C.; Hugo, E.R.; Hunt, P.A.; Newbold, R.R.; Rubin, B.S.; Saili, K.S.; et al. Low dose effects of bisphenol A. Endocr. Disruptors 2013, 1, e26490. [CrossRef]

54. Schirmer, E.; Schuster, S.; Machnik, P. Bisphenols exert detrimental effects on neuronal signaling in mature vertebrate brains. Commun. Biology 2021, 4, 465. [CrossRef] [PubMed]

55. Itoh, K.; Yaoi, T.; Fushiki, S. Bisphenol A, an endocrine-disrupting chemical, and brain development. Neuropathology 2012, 32, 447-457. [CrossRef] [PubMed]

56. Siracusa, J.S.; Yin, L.; Measel, E.; Liang, S.; Yu, X. Effects of bisphenol A and its analogs on reproductive health: A mini review. Reprod. Toxicol. 2018, 79, 96-123. [CrossRef]

57. Xu, J.; Huang, G.; Guo, T.L. Developmental Bisphenol A exposure modulates immune-related diseases. Toxics 2016, 4, 23. [CrossRef]

58. Wang, Y.; Rui, M.; Nie, Y.; Lu, G. Influence of gastrointestinal tract on metabolism of bisphenol A as determined by in vitro simulated system. J. Hazard. Mater. 2018, 355, 111-118. [CrossRef] [PubMed]

59. Moriyama, K.; Tagami, T.; Akamizu, T.; Usui, T.; Saijo, M.; Kanamoto, N.; Hataya, Y.; Shimatsu, A.; Kuzuya, H.; Nakao, K. Thyroid hormone action is disrupted by Bisphenol A as an antagonist. J. Clin. Endocrinol. Metab. 2002, 87, 5185-5190. [CrossRef] [PubMed] 
60. Thoene, M.; Rytel, L.; Dzika, E.; Włodarczyk, A.; Kruminis-Kaszkiel, E.; Konrad, P.; Wojtkiewicz, J. Bisphenol A causes liver damage and selectively alters the neurochemical coding of intrahepatic parasympathetic nerves in juvenile porcine models under physiological conditions. Int. J. Mol. Sci. 2017, 18, 2726. [CrossRef] [PubMed]

61. Gao, X.; Wang, H.-S. Impact of Bisphenol A on the cardiovascular system-Epidemiological and experimental evidence and molecular mechanisms. Int. J. Environ. Res. Public Health 2014, 11, 8399-8413. [CrossRef] [PubMed]

62. González-Parra, E.; Herrero, J.A.; Elewa, U.; Bosch, R.J.; Arduán, A.O.; Egido, J. Bisphenol A in chronic kidney disease. Int. J. Nephrol. 2013, 2013, 437857. [CrossRef]

63. Ben-Jonathan, N.; Hugo, E.R.; Brandebourg, T.D. Effects of Bisphenol A on adipokine release from human adipose tissue: Implications for the metabolic syndrome. Mol. Cell. Endocrinol. 2009, 304, 49-54. [CrossRef]

64. Kimura, E.; Matsuyoshi, C.; Miyazaki, W.; Benner, S.; Hosokawa, M.; Yokoyama, K.; Kakeyama, M.; Tohyama, C. Prenatal exposure to bisphenol A impacts neuronal morphology in the hippocampal CA1 region in developing and aged mice. Arch. Toxicol. 2016, 90, 691-700. [CrossRef] [PubMed]

65. Wolstenholme, J.T.; Rissman, E.F.; Connelly, J.J. The role of Bisphenol A in shaping the brain, epigenome and behavior. Horm. Behav. 2011, 59, 296-305. [CrossRef]

66. Stoner, R.; Chow, M.L.; Boyle, M.P.; Sunkin, S.M.; Mouton, P.R.; Roy, S.; Wynshaw-Boris, A.; Colamarino, S.A.; Lein, E.S.; Courchesne, E. Patches of disorganization in the neocortex of children with autism. N. Engl. J. Med. 2014, 370, 1209-1219. [CrossRef] [PubMed]

67. Nakamura, K.; Itoh, K.; Yaoi, T.; Fujiwara, Y.; Sugimoto, T.; Fushiki, S. Murine neocortical histogenesis is perturbed by prenatal exposure to low doses of Bisphenol A. J. Neurosci. Res. 2006, 84, 1197-1205. [CrossRef] [PubMed]

68. Wolstenholme, J.T.; Edwards, M.; Shetty, S.R.J.; Gatewood, J.D.; Taylor, J.A.; Rissman, E.F.; Connelly, J.J. Gestational exposure to Bisphenol A produces transgenerational changes in behaviors and gene expression. Endocrinology 2012, 153, $3828-3838$. [CrossRef]

69. Nguyen, U.; Tinsley, B.; Sen, Y.; Stein, J.; Palacios, Y.; Ceballos, A.; Welch, C.; Nzenkue, K.; Penn, A.; Murphy, L.; et al. Exposure to Bisphenol A differentially impacts neurodevelopment and behavior in Drosophila melanogaster from distinct genetic backgrounds. NeuroToxicology 2021, 82, 146-157. [CrossRef] [PubMed]

70. Perera, F.; Nolte, E.L.R.; Wang, Y.; Margolis, A.E.; Calafat, A.M.; Wang, S.; Garcia, W.; Hoepner, L.A.; Peterson, B.S.; Rauh, V.; et al. Bisphenol A exposure and symptoms of anxiety and depression among inner city children at 10-12 years of age. Environ. Res. 2016, 151, 195-202. [CrossRef]

71. Rochester, J.R.; Bolden, A.L.; Kwiatkowski, C.F. Prenatal exposure to bisphenol A and hyperactivity in children: A systematic review and meta-analysis. Environ. Int. 2018, 114, 343-356. [CrossRef] [PubMed]

72. Tewar, S.; Auinger, P.; Braun, J.M.; Lanphear, B.; Yolton, K.; Epstein, J.N.; Ehrlich, S.; Froehlich, T.E. Association of Bisphenol A exposure and attention-deficit/hyperactivity disorder in a national sample of U.S. children. Environ. Res. 2016, 150, 112-118. [CrossRef] [PubMed]

73. Lewis, M.H.; Tanimura, Y.; Lee, L.W.; Bodfish, J.W. Animal models of restricted repetitive behavior in autism. Behav. Brain Res. 2007, 176, 66-74. [CrossRef] [PubMed]

74. Olexová, L.; Štefánik, P.; Kršková, L. Increased anxiety-like behaviour and altered GABAergic system in the amygdala and cerebellum of VPA rats-An animal model of autism. Neurosci. Lett. 2016, 629, 9-14. [CrossRef] [PubMed]

75. Schneider, T.; Przewłocki, R. Behavioral alterations in rats prenatally exposed to valproic acid: Animal model of autism. Neuropsychopharmacology 2005, 30, 80-89. [CrossRef] [PubMed]

76. Seese, R.R.; Maske, A.R.; Lynch, G.; Gall, C.M. Long-term memory deficits are associated with elevated synaptic ERK1/2 activation and reversed by mGluR5 antagonism in an animal model of autism. Neuropsychopharmacology 2014, 39, 1664-1673. [CrossRef]

77. Castro, B.; Sánchez, P.; Torres, J.M.; Ortega, E. Effects of adult exposure to Bisphenol A on genes involved in the physiopathology of rat prefrontal cortex. PLoS ONE 2013, 8, e0073584. [CrossRef] [PubMed]

78. Arambula, S.E.; Belcher, S.M.; Planchart, A.; Turner, S.D.; Patisaul, H.B. Impact of low dose oral exposure to Bisphenol A (BPA) on the neonatal rat hypothalamic and hippocampal transcriptome: A CLARITY-BPA consortium study. Endocrinology 2016, 157, 3856-3872. [CrossRef] [PubMed]

79. Mathisen, G.H.; Yazdani, M.; Rakkestad, K.E.; Aden, P.K.; Bodin, J.; Samuelsen, M.; Nygaard, U.C.; Goverud, I.L.; Gaarder, M.; Løberg, E.M.; et al. Prenatal exposure to Bisphenol A interferes with the development of cerebellar granule neurons in mice and chicken. Int. J. Dev. Neurosci. 2013, 31, 762-769. [CrossRef]

80. Arambula, S.E.; Jima, D.; Patisaul, H.B. Prenatal bisphenol A (BPA) exposure alters the transcriptome of the neonate rat amygdala in a sex-specific manner: A CLARITY-BPA consortium study. NeuroToxicology 2018, 65, 207-220. [CrossRef]

81. Bicks, L.K.; Koike, H.; Akbarian, S.; Morishita, H. Prefrontal cortex and social cognition in mouse and man. Front. Psychol. 2015, 6, 1805. [CrossRef] [PubMed]

82. Yang, Y.; Raine, A. Prefrontal structural and functional brain imaging findings in antisocial, violent, and psychopathic individuals: A meta-analysis. Psychiatry Res. Neuroimaging 2009, 174, 81-88. [CrossRef]

83. Parker, A.; Derrington, A.; Blakemore, C.; Miller, E.K.; Freedman, D.J.; Wallis, J.D. The prefrontal cortex: Categories, concepts and cognition. Philos. Trans. R. Soc. B Biol. Sci. 2002, 357, 1123-1136. [CrossRef] 
84. Courchesne, E.; Mouton, P.R.; Calhoun, M.E.; Semendeferi, K.; Ahrens-Barbeau, C.; Hallet, M.J.; Barnes, C.C.; Pierce, K. Neuron number and size in prefrontal cortex of children with autism. JAMA 2011, 306, 2001-2010. [CrossRef]

85. Pitskel, N.B.; Bolling, D.Z.; Kaiser, M.D.; Pelphrey, K.A.; Crowley, M.J. Neural systems for cognitive reappraisal in children and adolescents with autism spectrum disorder. Dev. Cogn. Neurosci. 2014, 10, 117-128. [CrossRef]

86. Sarachana, T.; Xu, M.; Wu, R.-C.; Hu, V.W. Sex hormones in autism: Androgens and estrogens differentially and reciprocally regulate RORA, a novel candidate gene for autism. PloS ONE 2011, 6, e0017116. [CrossRef]

87. Hu, V.W.; Sarachana, T.; Sherrard, R.M.; Kocher, K.M. Investigation of sex differences in the expression of RORA and its transcriptional targets in the brain as a potential contributor to the sex bias in autism. Mol. Autism 2015, 6, 7. [CrossRef] [PubMed]

88. Sarachana, T.; Hu, V.W. Differential recruitment of coregulators to the RORA promoter adds another layer of complexity to gene (dys) regulation by sex hormones in autism. Mol. Autism 2013, 4, 39. [CrossRef] [PubMed]

89. Krämer, A.; Green, J.; Pollard, J., Jr.; Tugendreich, S. Causal analysis approaches in Ingenuity Pathway Analysis. Bioinformatics 2014, 30, 523-530. [CrossRef] [PubMed]

90. Yamagishi, S.; Bando, Y.; Sato, K. Involvement of netrins and their receptors in neuronal migration in the cerebral cortex. Front. Cell Dev. Biol. 2021, 8, 590009. [CrossRef]

91. Hori, K.; Nagai, T.; Shan, W.; Sakamoto, A.; Taya, S.; Hashimoto, R.; Hayashi, T.; Abe, M.; Yamazaki, M.; Nakao, K.; et al. Cytoskeletal regulation by AUTS2 in neuronal migration and neuritogenesis. Cell. Rep. 2014, 9, 2166-2179. [CrossRef]

92. Zhang, X.; Lei, K.; Yuan, X.; Wu, X.; Zhuang, Y.; Xu, T.; Xu, R.; Han, M. SUN1/2 and Syne/Nesprin-1/2 Complexes connect centrosome to the nucleus during neurogenesis and neuronal migration in mice. Neuron 2009, 64, 173-187. [CrossRef] [PubMed]

93. Gallagher, D.; Voronova, A.; Zander, M.A.; Cancino, G.I.; Bramall, A.; Krause, M.P.; Abad, C.; Tekin, M.; Neilsen, P.M.; Callen, D.F.; et al. Ankrd11 Is a chromatin regulator involved in autism that is essential for neural development. Dev. Cell 2015, 32, 31-42. [CrossRef] [PubMed]

94. Ka, M.; Kim, W.-Y. ANKRD11 associated with intellectual disability and autism regulates dendrite differentiation via the BDNF/TrkB signaling pathway. Neurobiol. Dis. 2018, 111, 138-152. [CrossRef]

95. Xiao, Y.; Peng, Y.; Wan, J.; Tang, G.; Chen, Y.; Tang, J.; Ye, W.-C.; Ip, N.Y.; Shi, L. The atypical guanine nucleotide exchange factor Dock4 regulates neurite differentiation through modulation of Rac1 GTPase and actin dynamics. J. Biol. Chem. 2013, 288, 20034-20045. [CrossRef] [PubMed]

96. Huang, X.; Cang, X.; Liu, J. Molecular mechanism of Bisphenol A on androgen receptor antagonism. Toxicol. Vitr. 2019, 61, 104621. [CrossRef]

97. Li, L.; Wang, Q.; Zhang, Y.; Niu, Y.; Yao, X.; Liu, H. The molecular mechanism of bisphenol A (BPA) as an endocrine disruptor by interacting with nuclear receptors: Insights from molecular dynamics (MD) simulations. PLoS ONE 2015, 10, e0120330. [CrossRef] [PubMed]

98. Beg, M.A.; Sheikh, I.A. Endocrine disruption: Molecular interactions of environmental bisphenol contaminants with thyroid hormone receptor and thyroxine-binding globulin. Toxicol. Ind. Health 2020, 36, 322-335. [CrossRef] [PubMed]

99. Lambert, S.A.; Jolma, A.; Campitelli, L.F.; Das, P.K.; Yin, Y.; Albu, M.; Chen, X.; Taipale, J.; Hughes, T.R.; Weirauch, M.T. The human transcription factors. Cell 2018, 172, 650-665. [CrossRef] [PubMed]

100. Abrahams, B.S.; Arking, D.E.; Campbell, D.B.; Mefford, H.C.; Morrow, E.M.; Weiss, L.A.; Menashe, I.; Wadkins, T.; Banerjee-Basu, S.; Packer, A. SFARI Gene 2.0: A community-driven knowledgebase for the autism spectrum disorders (ASDs). Mol. Autism 2013, 4, 36. [CrossRef] [PubMed]

101. Matys, V.; Fricke, E.; Geffers, R.; Gössling, E.; Haubrock, M.; Hehl, R.; Hornischer, K.; Karas, D.; Kel, A.E.; Kel-Margoulis, O.V.; et al. TRANSFAC: Transcriptional regulation, from patterns to profiles. Nucleic Acids Res. 2003, 31, 374-378. [CrossRef]

102. Matys, V.; Kel-Margoulis, O.V.; Fricke, E.; Liebich, I.; Land, S.; Barre-Dirrie, A.; Reuter, I.; Chekmenev, D.; Krull, M.; Hornischer, K.; et al. TRANSFAC and its module TRANSCompel: Transcriptional gene regulation in eukaryotes. Nucleic Acids Res. 2006, 34, D108-D110. [CrossRef]

103. Sarachana, T.; Hu, V.W. Genome-wide identification of transcriptional targets of RORA reveals direct regulation of multiple genes associated with autism spectrum disorder. Mol. Autism 2013, 4, 14. [CrossRef] [PubMed]

104. Kallen, J.A.; Schlaeppi, J.-M.; Bitsch, F.; Geisse, S.; Geiser, M.; Delhon, I.; Fournier, B. X-Ray Structure of the hROR $\alpha$ LBD at 1.63 $\AA$ : Structural and functional data that cholesterol or a cholesterol derivative is the natural ligand of ROR $\alpha$. Structure 2002, 10, 1697-1707. [CrossRef]

105. Ronald, A.; Hoekstra, R.A. Autism spectrum disorders and autistic traits: A decade of new twin studies. Am. J. Med Genet. Part B Neuropsychiatr. Genet. 2011, 156, 255-274. [CrossRef]

106. Bailey, A.; Le Couteur, A.; Gottesman, I.; Bolton, P.; Simonoff, E.; Yuzda, E.; Rutter, M. Autism as a strongly genetic disorder: Evidence from a British twin study. Psychol. Med. 1995, 25, 63-77. [CrossRef]

107. John, N.; Constantino, M.D.; Richard, D.; Todd, M.D. Genetic structure of reciprocal social behavior. Am. J. Psychiatry 2000, 157, 2043-2045. [CrossRef]

108. Gaugler, T.; Klei, L.; Sanders, S.J.; Bodea, C.A.; Goldberg, A.P.; Lee, A.B.; Mahajan, M.; Manaa, D.; Pawitan, Y.; Reichert, J.; et al. Most genetic risk for autism resides with common variation. Nat. Genet. 2014, 46, 881-885. [CrossRef] [PubMed]

109. Hallmayer, J.; Cleveland, S.; Torres, A.; Phillips, J.; Cohen, B.; Torigoe, T.; Miller, J.; Fedele, A.; Collins, J.; Smith, K.; et al. Genetic heritability and shared environmental factors among twin pairs with autism. Arch. Gen. Psychiatry 2011, 68, 1095-1102. [CrossRef] 
110. Edelson, L.R.; Saudino, K.J. Genetic and environmental influences on autistic-like behaviors in 2-year-old twins. Behav. Genet. 2009, 39, 255. [CrossRef]

111. Hoekstra, R.A.; Bartels, M.; Verweij, C.J.H.; Boomsma, D.I. Heritability of autistic traits in the general population. Arch. Pediatrics Adolesc. Med. 2007, 161, 372-377. [CrossRef] [PubMed]

112. Deng, W.; Zou, X.; Deng, H.; Li, J.; Tang, C.; Wang, X.; Guo, X. The relationship among genetic heritability, environmental effects, and autism spectrum disorders. J. Child Neurol. 2015, 30, 1794-1799. [CrossRef] [PubMed]

113. Miodovnik, A.; Engel, S.M.; Zhu, C.; Ye, X.; Soorya, L.V.; Silva, M.J.; Calafat, A.M.; Wolff, M.S. Endocrine disruptors and childhood social impairment. NeuroToxicology 2011, 32, 261-267. [CrossRef]

114. Evans, S.F.; Kobrosly, R.W.; Barrett, E.S.; Thurston, S.W.; Calafat, A.M.; Weiss, B.; Stahlhut, R.; Yolton, K.; Swan, S.H. Prenatal Bisphenol A exposure and maternally reported behavior in boys and girls. NeuroToxicology 2014, 45, 91-99. [CrossRef]

115. Harley, K.G.; Gunier, R.B.; Kogut, K.; Johnson, C.; Bradman, A.; Calafat, A.M.; Eskenazi, B. Prenatal and early childhood bisphenol A concentrations and behavior in school-aged children. Environ. Res. 2013, 126, 43-50. [CrossRef] [PubMed]

116. Perera, F.; Vishnevetsky, J.; Herbstman, J.B.; Calafat, A.M.; Xiong, W.; Rauh, V.; Wang, S. Prenatal Bisphenol A exposure and child behavior in an inner-city cohort. Environ. Health Perspect. 2012, 120, 1190-1194. [CrossRef] [PubMed]

117. Roen, E.L.; Wang, Y.; Calafat, A.M.; Wang, S.; Margolis, A.; Herbstman, J.; Hoepner, L.A.; Rauh, V.; Perera, F.P. Bisphenol A exposure and behavioral problems among inner city children at 7-9 years of age. Environ. Res. 2015, 142, 739-745. [CrossRef] [PubMed]

118. Philippat, C.; Nakiwala, D.; Calafat, A.M.; Botton, J.; Agostini, M.D.; Heude, B.; Slama, R. Prenatal Exposure to nonpersistent endocrine disruptors and behavior in boys at 3 and 5 years. Environ. Health Perspect. 2017, 125, 097014. [CrossRef] [PubMed]

119. Lim, Y.-H.; Bae, S.; Kim, B.-N.; Shin, C.H.; Lee, Y.A.; Kim, J.I.; Hong, Y.-C. Prenatal and postnatal bisphenol A exposure and social impairment in 4-year-old children. Environ. Health 2017, 16, 79. [CrossRef] [PubMed]

120. Braun, J.M.; Yolton, K.; Dietrich, K.N.; Hornung, R.; Ye, X.; Calafat, A.M.; Lanphear, B.P. Prenatal Bisphenol a exposure and early childhood behavior. Environ. Health Perspect. 2009, 117, 1945-1952. [CrossRef] [PubMed]

121. Braun, J.M.; Kalkbrenner, A.E.; Calafat, A.M.; Yolton, K.; Ye, X.; Dietrich, K.N.; Lanphear, B.P. Impact of early-life Bisphenol A exposure on behavior and executive function in children. Pediatrics 2011, 128, 873-882. [CrossRef] [PubMed]

122. Stacy, S.L.; Papandonatos, G.D.; Calafat, A.M.; Chen, A.; Yolton, K.; Lanphear, B.P.; Braun, J.M. Early life Bisphenol A exposure and neurobehavior at 8 years of age: Identifying windows of heightened vulnerability. Environ. Int. 2017, 107, 258-265. [CrossRef] [PubMed]

123. Donovan, A.P.A.; Basson, M.A. The neuroanatomy of autism-A developmental perspective. J. Anat. 2017, 230, 4-15. [CrossRef] [PubMed]

124. Palmen, S.J.M.C.; van Engeland, H.; Hof, P.R.; Schmitz, C. Neuropathological findings in autism. Brain 2004, 127, $2572-2583$. [CrossRef] [PubMed]

125. Sukjamnong, S.; Thongkorn, S.; Kanlayaprasit, S.; Saeliw, T.; Hussem, K.; Warayanon, W.; Hu, V.W.; Tencomnao, T.; Sarachana, T. Prenatal exposure to bisphenol A alters the transcriptome-interactome profiles of genes associated with Alzheimer's disease in the offspring hippocampus. Sci. Rep. 2020, 10, 9487. [CrossRef]

126. Volkmar, F.R.; Lord, C.; Bailey, A.; Schultz, R.T.; Klin, A. Autism and pervasive developmental disorders. J. Child Psychol. Psychiatry 2004, 45, 135-170. [CrossRef]

127. Licari, M.K.; Alvares, G.A.; Varcin, K.; Evans, K.L.; Cleary, D.; Reid, S.L.; Glasson, E.J.; Bebbington, K.; Reynolds, J.E.; Wray, J.; et al. Prevalence of motor difficulties in autism spectrum disorder: Analysis of a population-based cohort. Autism Res. 2020, 13, 298-306. [CrossRef]

128. Zheng, Z.; Zheng, P.; Zou, X. Association between schizophrenia and autism spectrum disorder: A systematic review and meta-analysis. Autism Res. 2018, 11, 1110-1119. [CrossRef] [PubMed]

129. Srivastava, S.; Sahin, M. Autism spectrum disorder and epileptic encephalopathy: Common causes, many questions. J. Neurodev. Disord. 2017, 9, 23. [CrossRef] [PubMed]

130. DeRosa, B.A.; El Hokayem, J.; Artimovich, E.; Garcia-Serje, C.; Phillips, A.W.; Van Booven, D.; Nestor, J.E.; Wang, L.; Cuccaro, M.L.; Vance, J.M.; et al. Convergent pathways in idiopathic autism revealed by time course transcriptomic analysis of patient-derived neurons. Sci. Rep. 2018, 8, 8423. [CrossRef]

131. Rademacher, S.; Eickholt, B.J. PTEN in autism and neurodevelopmental disorders. Cold Spring Harb. Perspect. Med. 2019, 9, a036780. [CrossRef]

132. Jung, N.H.; Janzarik, W.G.; Delvendahl, I.; Münchau, A.; Biscaldi, M.; Mainberger, F.; Bäumer, T.; Rauh, R.; Mall, V. Impaired induction of long-term potentiation-like plasticity in patients with high-functioning autism and Asperger syndrome. Dev. Med. Child Neurol. 2013, 55, 83-89. [CrossRef]

133. Hansel, C. Deregulation of synaptic plasticity in autism. Neurosci. Lett. 2019, 688, 58-61. [CrossRef] [PubMed]

134. Kwan, V.; Unda, B.K.; Singh, K.K. Wnt signaling networks in autism spectrum disorder and intellectual disability. J. Neurodev. Disord. 2016, 8, 45. [CrossRef] [PubMed]

135. Lee, C.Y.; Hyun, S.-A.; Ko, M.Y.; Kim, H.R.; Rho, J.; Kim, K.K.; Kim, W.-Y.; Ka, M. Maternal Bisphenol A (BPA) exposure alters cerebral cortical morphogenesis and synaptic function in mice. Cereb. Cortex 2021, 31, 5598-5612. [CrossRef] 
136. Schafer, S.T.; Paquola, A.C.M.; Stern, S.; Gosselin, D.; Ku, M.; Pena, M.; Kuret, T.J.M.; Liyanage, M.; Mansour, A.A.; Jaeger, B.N.; et al. Pathological priming causes developmental gene network heterochronicity in autistic subject-derived neurons. Nat. Neurosci. 2019, 22, 243-255. [CrossRef] [PubMed]

137. Marchetto, M.C.; Belinson, H.; Tian, Y.; Freitas, B.C.; Fu, C.; Vadodaria, K.C.; Beltrao-Braga, P.C.; Trujillo, C.A.; Mendes, A.P.D.; Padmanabhan, K.; et al. Altered proliferation and networks in neural cells derived from idiopathic autistic individuals. Mol. Psychiatry 2017, 22, 820-835. [CrossRef] [PubMed]

138. Quartier, A.; Chatrousse, L.; Redin, C.; Keime, C.; Haumesser, N.; Maglott-Roth, A.; Brino, L.; Le Gras, S.; Benchoua, A.; Mandel, J.-L.; et al. Genes and pathways regulated by androgens in human neural cells, potential candidates for the male excess in autism spectrum disorder. Biol. Psychiatry 2018, 84, 239-252. [CrossRef]

139. Baron-Cohen, S.; Tsompanidis, A.; Auyeung, B.; Nørgaard-Pedersen, B.; Hougaard, D.M.; Abdallah, M.; Cohen, A.; Pohl, A. Foetal oestrogens and autism. Mol. Psychiatry 2020, 25, 2970-2978. [CrossRef]

140. Chen, S.; Novick, P.; Ferro-Novick, S. ER network formation requires a balance of the dynamin-like GTPase Sey1p and the Lunapark family member Lnp1p. Nat. Cell Biol. 2012, 14, 707-716. [CrossRef]

141. Breuss, M.W.; Nguyen, A.; Song, Q.; Nguyen, T.; Stanley, V.; James, K.N.; Musaev, D.; Chai, G.; Wirth, S.A.; Anzenberg, P.; et al. Mutations in LNPK, Encoding the endoplasmic reticulum junction stabilizer lunapark, cause a recessive neurodevelopmental syndrome. Am. J. Hum. Genet. 2018, 103, 296-304. [CrossRef] [PubMed]

142. Lim, D.A.; Huang, Y.-C.; Swigut, T.; Mirick, A.L.; Garcia-Verdugo, J.M.; Wysocka, J.; Ernst, P.; Alvarez-Buylla, A. Chromatin remodelling factor Mll1 is essential for neurogenesis from postnatal neural stem cells. Nature 2009, 458, 529-533. [CrossRef]

143. Potts, M.B.; Siu, J.J.; Price, J.D.; Salinas, R.D.; Cho, M.J.; Ramos, A.D.; Hahn, J.; Margeta, M.; Oldham, M.C.; Lim, D.A. Analysis of Mll1 Deficiency identifies neurogenic transcriptional modules and brn4 as a factor for direct astrocyte-to-neuron reprogramming. Neurosurgery 2014, 75, 472-482. [CrossRef]

144. Jakovcevski, M.; Ruan, H.; Shen, E.Y.; Dincer, A.; Javidfar, B.; Ma, Q.; Peter, C.J.; Cheung, I.; Mitchell, A.C.; Jiang, Y.; et al. Neuronal Kmt2a/Mll1 histone methyltransferase is essential for prefrontal synaptic plasticity and working memory. J. Neurosci. 2015, 35, 5097-5108. [CrossRef]

145. Shen, E.Y.; Jiang, Y.; Javidfar, B.; Kassim, B.; Loh, Y.-H.E.; Ma, Q.; Mitchell, A.C.; Pothula, V.; Stewart, A.F.; Ernst, P.; et al. Neuronal deletion of Kmt2a/Mll1 Histone methyltransferase in ventral striatum is associated with defective spike-timing-dependent striatal synaptic plasticity, altered response to dopaminergic drugs, and increased anxiety. Neuropsychopharmacology 2016, 41, 3103-3113. [CrossRef] [PubMed]

146. Chan, A.J.S.; Cytrynbaum, C.; Hoang, N.; Ambrozewicz, P.M.; Weksberg, R.; Drmic, I.; Ritzema, A.; Schachar, R.; Walker, S.; Uddin, M.; et al. Expanding the neurodevelopmental phenotypes of individuals with de novo KMT2A variants. NPJ Genom. Med. 2019, 4, 9. [CrossRef]

147. Wilson, N.H.; Key, B. Neogenin interacts with RGMa and Netrin-1 to guide axons within the embryonic vertebrate forebrain. Dev. Biol. 2006, 296, 485-498. [CrossRef] [PubMed]

148. Fitzgerald, D.P.; Cole, S.J.; Hammond, A.; Seaman, C.; Cooper, H.M. Characterization of neogenin-expressing neural progenitor populations and migrating neuroblasts in the embryonic mouse forebrain. Neuroscience 2006, 142, 703-716. [CrossRef] [PubMed]

149. Sun, D.; Sun, X.-D.; Zhao, L.; Lee, D.-H.; Hu, J.-X.; Tang, F.-L.; Pan, J.-X.; Mei, L.; Zhu, X.-J.; Xiong, W.-C. Neogenin, a regulator of adult hippocampal neurogenesis, prevents depressive-like behavior. Cell Death Dis. 2018, 9, 8. [CrossRef] [PubMed]

150. Siu, W.-K.; Lam, C.-W.; Gao, W.-W.; Vincent Tang, H.-M.; Jin, D.-Y.; Mak, C.M. Unmasking a novel disease gene NEO1 associated with autism spectrum disorders by a hemizygous deletion on chromosome 15 and a functional polymorphism. Behav. Brain Res. 2016, 300, 135-142. [CrossRef] [PubMed]

151. Lin, J.C.; Ho, W.-H.; Gurney, A.; Rosenthal, A. The netrin-G1 ligand NGL-1 promotes the outgrowth of thalamocortical axons. Nat. Neurosci. 2003, 6, 1270-1276. [CrossRef] [PubMed]

152. Sun, K.L.W.; Correia, J.P.; Kennedy, T.E. Netrins: Versatile extracellular cues with diverse functions. Development 2011, $138,2153$. [CrossRef] [PubMed]

153. Fujita, Y.; Nakanishi, T.; Ueno, M.; Itohara, S.; Yamashita, T. Netrin-G1 Regulates microglial accumulation along axons and supports the survival of layer V neurons in the postnatal mouse brain. Cell Rep. 2020, 31, 107580. [CrossRef] [PubMed]

154. Zhang, Q.; Goto, H.; Akiyoshi-Nishimura, S.; Prosselkov, P.; Sano, C.; Matsukawa, H.; Yaguchi, K.; Nakashiba, T.; Itohara, S. Diversification of behavior and postsynaptic properties by netrin-G presynaptic adhesion family proteins. Mol. Brain 2016, 9, 6 . [CrossRef]

155. O’Roak, B.J.; Vives, L.; Girirajan, S.; Karakoc, E.; Krumm, N.; Coe, B.P.; Levy, R.; Ko, A.; Lee, C.; Smith, J.D.; et al. Sporadic autism exomes reveal a highly interconnected protein network of de novo mutations. Nature 2012, 485, 246-250. [CrossRef] [PubMed]

156. Borg, I.; Freude, K.; Kübart, S.; Hoffmann, K.; Menzel, C.; Laccone, F.; Firth, H.; Ferguson-Smith, M.A.; Tommerup, N.; Ropers, H.-H.; et al. Disruption of Netrin G1 by a balanced chromosome translocation in a girl with rett syndrome. Eur. J. Hum. Genet. 2005, 13, 921-927. [CrossRef]

157. Bedogni, F.; Hodge, R.D.; Nelson, B.R.; Frederick, E.A.; Shiba, N.; Daza, R.A.; Hevner, R.F. Autism susceptibility candidate 2 (Auts2) encodes a nuclear protein expressed in developing brain regions implicated in autism neuropathology. Gene Expr. Patterns 2010, 10, 9-15. [CrossRef] [PubMed]

158. Oksenberg, N.; Ahituv, N. The role of AUTS2 in neurodevelopment and human evolution. Trends Genet. 2013, 29, 600-608. [CrossRef] [PubMed] 
159. Nagamani, S.C.S.; Erez, A.; Ben-Zeev, B.; Frydman, M.; Winter, S.; Zeller, R.; El-Khechen, D.; Escobar, L.; Stankiewicz, P.; Patel, A.; et al. Detection of copy-number variation in AUTS2 gene by targeted exonic array CGH in patients with developmental delay and autistic spectrum disorders. Eur. J. Hum. Genet. 2013, 21, 343-346. [CrossRef] [PubMed]

160. Liu, Y.; Zhao, D.; Dong, R.; Yang, X.; Zhang, Y.; Tammimies, K.; Uddin, M.; Scherer, S.W.; Gai, Z. De novo exon 1 deletion of AUTS2 gene in a patient with autism spectrum disorder and developmental delay: A case report and a brief literature review. Am. J. Med. Genet. Part A 2015, 167, 1381-1385. [CrossRef] [PubMed]

161. Beunders, G.; Voorhoeve, E.; Golzio, C.; Pardo, L.M.; Rosenfeld, J.A.; Talkowski, M.E.; Simonic, I.; Lionel, A.C.; Vergult, S.; Pyatt, R.E.; et al. Exonic deletions in AUTS2 cause a syndromic form of intellectual disability and suggest a critical role for the C terminus. Am. J. Hum. Genet. 2013, 92, 210-220. [CrossRef] [PubMed]

162. Ben-David, E.; Granot-Hershkovitz, E.; Monderer-Rothkoff, G.; Lerer, E.; Levi, S.; Yaari, M.; Ebstein, R.P.; Yirmiya, N.; Shifman, S. Identification of a functional rare variant in autism using genome-wide screen for monoallelic expression. Hum. Mol. Genet. 2011, 20, 3632-3641. [CrossRef] [PubMed]

163. Oksenberg, N.; Stevison, L.; Wall, J.D.; Ahituv, N. Function and regulation of AUTS2, a gene implicated in autism and human evolution. PLoS Genet. 2013, 9, e1003221. [CrossRef] [PubMed]

164. Hori, K.; Yamashiro, K.; Nagai, T.; Shan, W.; Egusa, S.F.; Shimaoka, K.; Kuniishi, H.; Sekiguchi, M.; Go, Y.; Tatsumoto, S.; et al. AUTS2 regulation of synapses for proper synaptic inputs and social communication. iScience 2020, 23, 101183. [CrossRef] [PubMed]

165. Marshall, C.R.; Noor, A.; Vincent, J.B.; Lionel, A.C.; Feuk, L.; Skaug, J.; Shago, M.; Moessner, R.; Pinto, D.; Ren, Y.; et al. Structural variation of chromosomes in autism spectrum disorder. Am. J. Hum. Genet. 2008, 82, 477-488. [CrossRef] [PubMed]

166. Willemsen, M.H.; Fernandez, B.A.; Bacino, C.A.; Gerkes, E.; de Brouwer, A.P.M.; Pfundt, R.; Sikkema-Raddatz, B.; Scherer, S.W.; Marshall, C.R.; Potocki, L.; et al. Identification of ANKRD11 and ZNF778 as candidate genes for autism and variable cognitive impairment in the novel 16q24.3 microdeletion syndrome. Eur. J. Hum. Genet. 2010, 18, 429-435. [CrossRef] [PubMed]

167. Bucerzan, S.; Miclea, D.; Lazea, C.; Asavoaie, C.; Kulcsar, A.; Grigorescu-Sido, P. 16q24.3 microduplication in a patient with developmental delay, intellectual disability, short stature, and nonspecific dysmorphic features: Case Report and review of the literature. Front. Pediatr. 2020, 8, 390. [CrossRef] [PubMed]

168. Crippa, M.; Rusconi, D.; Castronovo, C.; Bestetti, I.; Russo, S.; Cereda, A.; Selicorni, A.; Larizza, L.; Finelli, P. Familial intragenic duplication of ANKRD11 underlying three patients of KBG syndrome. Mol. Cytogenet. 2015, 8, 20. [CrossRef] [PubMed]

169. Acconcia, F.; Pallottini, V.; Marino, M. Molecular mechanisms of action of BPA. Dose Response 2015, 13, 1559325815610582. [CrossRef] [PubMed]

170. Kong, Y.; Zhou, W.; Sun, Z. Nuclear receptor corepressors in intellectual disability and autism. Mol. Psychiatry 2020, 25, 2220-2236. [CrossRef] [PubMed]

171. Sun, Z.; Xu, Y. Nuclear receptor coactivators (NCOAs) and corepressors (NCORs) in the brain. Endocrinology 2020, 161, bqaa083. [CrossRef] [PubMed]

172. Kikkawa, T.; Casingal, C.R.; Chun, S.H.; Shinohara, H.; Hiraoka, K.; Osumi, N. The role of Pax6 in brain development and its impact on pathogenesis of autism spectrum disorder. Brain Res. 2019, 1705, 95-103. [CrossRef]

173. Lachmann, A.; Xu, H.; Krishnan, J.; Berger, S.I.; Mazloom, A.R.; Ma'ayan, A. ChEA: Transcription factor regulation inferred from integrating genome-wide ChIP-X experiments. Bioinformatics 2010, 26, 2438-2444. [CrossRef]

174. The ENCODE (ENCyclopedia Of DNA Elements) Project. Science 2004, 306, 636-640. [CrossRef] [PubMed]

175. Jin, H.-J.; Kim, J.; Yu, J. Androgen receptor genomic regulation. Transl. Androl. Urol. 2013, 2, 157-177. [CrossRef]

176. Nguyen, A.; Rauch, T.A.; Pfeifer, G.P.; Hu, V.W. Global methylation profiling of lymphoblastoid cell lines reveals epigenetic contributions to autism spectrum disorders and a novel autism candidate gene, RORA, whose protein product is reduced in autistic brain. FASEB J. 2010, 24, 3036-3051. [CrossRef] [PubMed]

177. Spijker, S. Dissection of rodent brain regions. In Neuroproteomics; Humana Press: Totowa, NJ, USA, $2011 ;$ pp. $13-26$.

178. Guo, W.; Patzlaff, N.E.; Jobe, E.M.; Zhao, X. Isolation of multipotent neural stem or progenitor cells from both the dentate gyrus and subventricular zone of a single adult mouse. Nat. Protoc. 2012, 7, 2005-2012. [CrossRef] [PubMed]

179. Langmead, B.; Salzberg, S.L. Fast gapped-read alignment with Bowtie 2. Nat. Methods 2012, 9, 357-359. [CrossRef] [PubMed]

180. Li, B.; Dewey, C.N. RSEM: Accurate transcript quantification from RNA-Seq data with or without a reference genome. BMC Bioinform. 2011, 12, 323. [CrossRef] [PubMed]

181. Kent, W.J.; Sugnet, C.W.; Furey, T.S.; Roskin, K.M.; Pringle, T.H.; Zahler, A.M.; Haussler, A.D. The Human genome browser at UCSC. Genome Res. 2002, 12, 996-1006. [CrossRef]

182. Howe, K.L.; Achuthan, P.; Allen, J.; Allen, J.; Alvarez-Jarreta, J.; Amode, M.R.; Armean, I.M.; Azov, A.G.; Bennett, R.; Bhai, J.; et al. Ensembl 2021. Nucleic Acids Res. 2020, 49, D884-D891. [CrossRef] [PubMed]

183. Untergasser, A.; Cutcutache, I.; Koressaar, T.; Ye, J.; Faircloth, B.C.; Remm, M.; Rozen, S.G. Primer3—new capabilities and interfaces. Nucleic Acids Res. 2012, 40, e115. [CrossRef] [PubMed]

184. Koressaar, T.; Remm, M. Enhancements and modifications of primer design program Primer3. Bioinformatics 2007, 23, 1289-1291. [CrossRef] [PubMed]

185. Kõressaar, T.; Lepamets, M.; Kaplinski, L.; Raime, K.; Andreson, R.; Remm, M. Primer3_masker: Integrating masking of template sequence with primer design software. Bioinformatics 2018, 34, 1937-1938. [CrossRef] [PubMed] 
186. Edgar, R.; Domrachev, M.; Lash, A.E. Gene expression omnibus: NCBI gene expression and hybridization array data repository. Nucleic Acids Res. 2002, 30, 207-210. [CrossRef]

187. Howe, E.A.; Sinha, R.; Schlauch, D.; Quackenbush, J. RNA-Seq analysis in MeV. Bioinformatics 2011, 27, 3209-3210. [CrossRef] [PubMed]

188. Jumper, J.; Evans, R.; Pritzel, A.; Green, T.; Figurnov, M.; Ronneberger, O.; Tunyasuvunakool, K.; Bates, R.; Žídek, A.; Potapenko, A.; et al. Highly accurate protein structure prediction with AlphaFold. Nature 2021, 596, 583-589. [CrossRef] [PubMed]

189. Morris, G.M.; Huey, R.; Lindstrom, W.; Sanner, M.F.; Belew, R.K.; Goodsell, D.S.; Olson, A.J. AutoDock4 and AutoDockTools4: Automated docking with selective receptor flexibility. J. Comput. Chem. 2009, 30, 2785-2791. [CrossRef] [PubMed] 